\title{
Energy Storage System Selection for Optimal Fuel Consumption of Aircraft Hybrid Electric Taxiing System
}

Angel Recalde ${ }^{1}$, Milos Lukic ${ }^{1}$, Ahmed Hebala ${ }^{1}$, Paolo Giangrande ${ }^{1}$, Christian Klumpner ${ }^{1}$, Stefano Nuzzo ${ }^{1,2}$, Peter H. Connor ${ }^{1}$, Jason Atkin ${ }^{3}$, Serhiy Bozhko ${ }^{1,4}$, Michael Galea ${ }^{1,4}$

${ }^{1}$ PEMC, University of Nottingham, UK

${ }^{2}$ Department of Engineering Enzo Ferrari within University degli Studi di Modena e Reggio Emilia, Italy

${ }^{3}$ COL Lab, School of Computer Science, University of Nottingham, UK

${ }^{4}$ University of Nottingham, Ningbo, China angel.recaldelino@,nottingham.ac.uk, Aerospace Technology Center, NG7 2TU

Abstract-Aircraft taxiing is conventionally performed using the main engines' inefficient idle thrust. Therefore, in line with greener aviation, the electrification of taxiing is the most viable option to reduce emissions, noise, and fossil fuel consumption during ground operations. This paper studies the potential of hybridising the conventional electric taxiing system, which is currently driven by the Auxiliary Power Unit, with an electrical energy storage system, comprising commercial high-energy and high-power lithium-ion batteries, for the purpose of reducing fuel consumption. Hence, a power distribution optimisation is formulated to minimise fuel consumption over a typical worst-case taxi-out profile. Three different energy management strategies are presented for a narrow-body aeroplane. The optimisation is performed for the selection of off-the-shelf batteries so that their impact on fuel savings can be evaluated in the early design stage.

The study showed that a wide range of savings is achievable according to the selected strategy, the added weight allowance and the battery characteristics. Considering a $180 \mathrm{~kg}$ added weight allowance and covering the three investigated strategies, up to $72 \%$ of taxiing fuel is saved.

Keywords-More Electric Aircraft, Energy Storage System, Electric Taxiing, Taxiing System Optimisation, Lithium Ion Batteries

\section{NOMENCLATURE}

CT Conventional taxiing

ET/ETS Electric taxiing / Electric taxiing systems

APU Auxiliary Power Unit

ATRU Auto-transformer rectifier unit

CET Conventional electric taxiing

AET All electric taxiing 


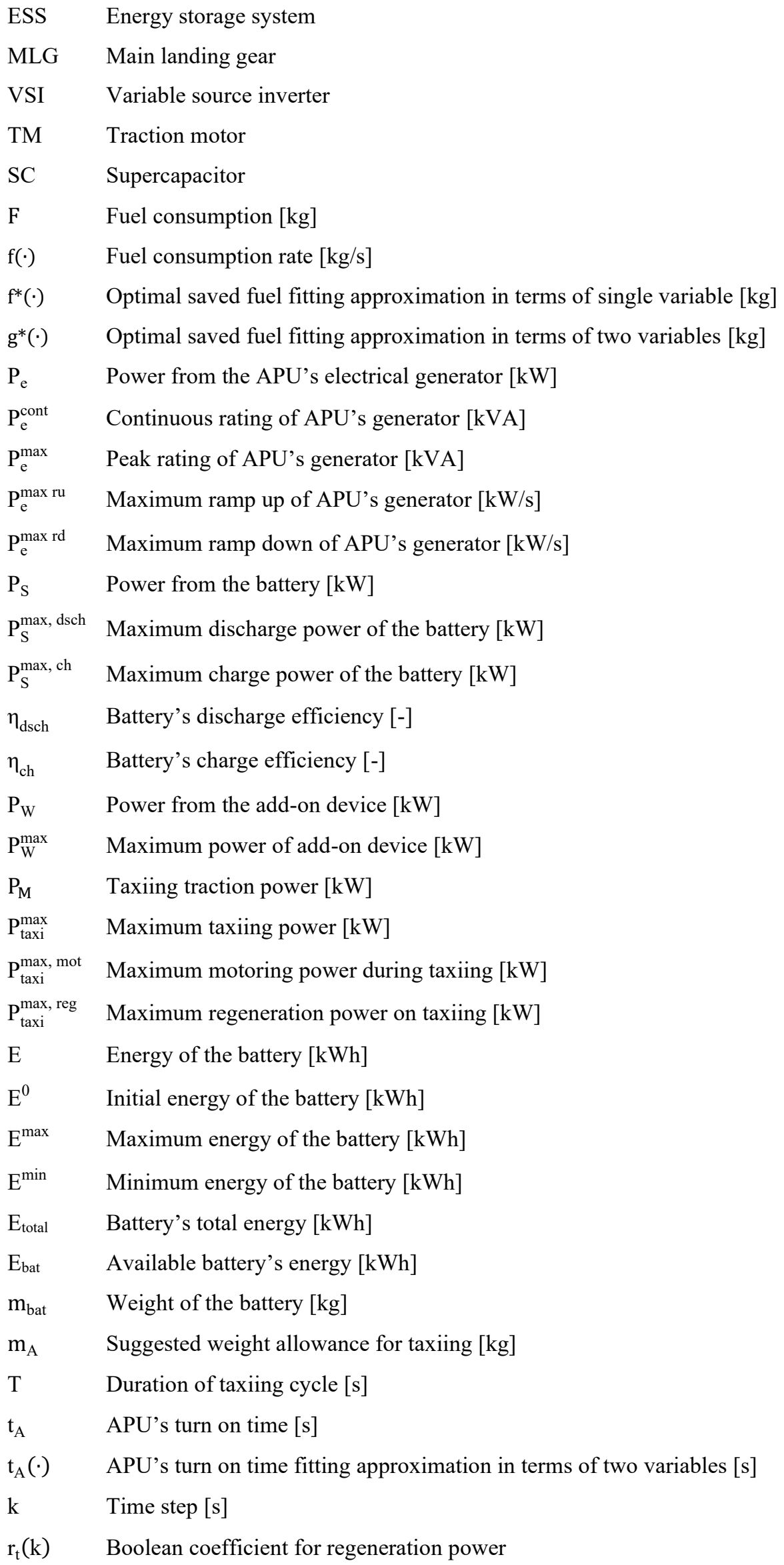




\section{INTRODUCTION}

Unless the current scenarios change, the forecast increase in air travel will soon lead to higher levels of air pollutants. Indeed, it is expected that by 2040 the $\mathrm{CO}_{2}$ and $\mathrm{NO}_{\mathrm{X}}$ emissions are going to increase by at least $21 \%$ and $16 \%$, respectively [1]. Therefore, measures for reducing aircraft emissions have been adopted by both manufacturers and operators. Numerous actions have already been put into place to comply with these regulations. For example, the International Civil Aviation Organisation has defined the environmental impact of taxiing as the combined effect of perceived noise on the ground, local air quality and climate change. Logically, the airborne phase is the most demanding and represents the largest contributor to emissions and noise. Yet, ground operations also contribute, so they are also targeted for improvements.

A major role of the ground operations is taxiing. Taxiing is defined as the flight phase in which the movement of an aircraft occurs on the surface of an aerodrome under its own power, i.e., using jet engines, excluding takeoff and landing. This definition will be referred to as conventional taxiing (CT) throughout the text [1]-[3]. During CT, an aircraft's engines are set to the inefficient idle thrust of $7 \%$, with an average fuel consumption index of $0.1011 \mathrm{~kg} / \mathrm{s}$ per engine [4]. Therefore, $364 \mathrm{~kg}$ of fuel is needed for 30 minutes of dual-engine CT. In [4], [5], it is estimated that the taxiing phase can account for up to $6 \%$ of the total fuel consumption in the case of short-haul flights, and this is estimated to add up to an annual total fuel consumption worldwide of 5 million tons. Additionally, the aircraft fuel cost is more than a third of airline companies' operating expenses [4], [6]. Therefore, the European Union (EU) introduced 2050 Flight Path Strategy with ambitious environmental goals to cut emissions of $\mathrm{NO}_{\mathrm{x}}$ by $90 \%, \mathrm{CO}_{2}$ by $70 \%$ and noise levels to half of 2000 standard values [7], [8]. Besides, all aircraft movements while taxiing are required to be emission-free according to the 2050 target [9]. Hence, many solutions have been proposed which avoid using jet engines during this critical phase. In line with the more electric aircraft initiative, it is widely accepted in the aerospace community that electrification of taxiing procedure (i.e., electric taxiing (ET) solutions [10], [11]) is the most promising option for achieving emission-free ground movement. The ET solutions can be divided into on-board and external ones. Simplistically, the external ET systems (ETS) rely upon the replacement of diesel-based tugs with electrical or hybrid electric tractors, such as Mototok [12] and Taxibot [2], [13]. On the other hand, the on-board ETS require installation of electric motors and accompanying equipment (cables, control units, casings, etc.) inside the wheels of the landing gear that provide the traction power to move the aircraft on the ground. The on-board ETS solutions are a preferable choice compared to their external counterparts as they improve aircraft 
autonomy. Despite the fact that ETS represent a deadweight during flight, on-board ETS are proven to have significant block-fuel savings (fuel for the whole flight mission) and, therefore, are the focus of this paper.

The most studied on-board ETS configuration is the one in which electric motors are supplied by the auxiliary power unit (APU) driven electrical generator through an auto-transformer rectifier unit (ATRU) [14]. These solutions are being led by major aerospace manufacturers such as Safran and Airbus [2], [13], and in this paper, are referred to as conventional electric taxiing (CET). Although they have a lot of potential for fuelefficiency improvements, they still rely upon the APU utilisation for power supply, which consumes fuel, produces emissions and generates noise. Nonetheless, studies have shown that block-fuel savings between $1 \%$ and 4\%, and significant emission reductions can be achieved using APUs in CET [15]-[17]. The figures depend on the weight of the ETS, flight distance and total taxiing time. On the other hand, with the goal of achieving carbon-free and noiseless aircraft ground movement, the ET drive must be powered from sources using noncarbon fuels, for instance, batteries, supercapacitors, and fuel cells or a combination of them all [18]. Such ET solutions that use electrochemical energy as the sole powering source are going to be termed in this paper allelectric taxiing (AET) solutions.

Having in mind that as of 2020 there is no commercially available on-board ETS, it is logical that CET solutions are the first step towards the fuel reduction through electrification, since their implementation would not require major changes of other aircraft systems and can be easily retrofitted to the current aeroplane models. Existing environmental control systems and jet-engine starting procedures require pneumatic power, which in the case of CET, is provided by the APU. Contrastingly, the installation of AET systems would require changes to these systems and protocols, due to the fact that the APU is turned-off during taxiing procedures. Indeed, a noiseless and carbon-free AET can be introduced only once environmental control systems become electric, and the starting of the engines becomes bleedless, such as those found in the Boeing 787 Dreamliner.

Similarly to the automotive industry, where hybrid electric vehicles are introduced as a bridge between fully electric and conventional gas vehicles, a hybrid ETS can bring taxiing electrification from the CET level closer to the AET level from the fuel consumption and emissions point of view. To this purpose, a second power source (i.e., energy storage system - ESS) is introduced with the aim of reducing the ETS dependency on the fossil-fuel powered APU and, consequently, to minimise consumed fuel and ensuing pollution and noise during taxiing. The selected ESSs in this study are battery based, as batteries have reached a certain maturity level and are already extensively used in various traction applications. Considering that ET is essentially a traction application, this means that the already implemented battery solutions in other vehicle types can be conveniently adapted to ET 
requirements. Also, it is considered that taxiing and engine warm-up phases are independent. Therefore, even though engine warm-up represents an impediment for more efficient implementation of ET, this aspect is not addressed.

In this paper, the deployment of a hybrid ETS is explored considering an ESS based on batteries of different sizes, types and characteristics. The investigation on fuel consumption reduction and total added weight is performed for a medium size aircraft following a demanding - both in duration and power required - taxiing profile as a worst-case taxiing cycle scenario. Furthermore, as fuel consumption also depends on the adopted energy management strategy (EMS) [19], three different EMSs are presented in this study, which correspond to different levels of hybridisation between CET and AET. Practically, the hybridised ETS resembles the powertrain of a series hybrid electric vehicle with the difference that the APU is used instead of a diesel/petrol engine, for which many techniques have been proposed that deal with fuel consumption minimisation and they can be broadly categorised into control-based and optimisation-based approaches [20], [21].

Control-based or rule-based approaches require a decision-tree (i.e., control law), which manages and distributes the power contributions of both ESS and APU [22], [23]. However, different control laws yield different outcomes for fuel consumption. Thus, one could argue that there is an improved control law which achieves increased fuel economy [24], [25]. In contrast, the optimisation approaches aim to search through all the feasible design space of all possible APU and ESS combined power distributions such that the maximum fuel economy could be obtained, also known as global optimum [26]. Therefore, to avoid the utilisation of control laws and their associated drawbacks [22], [24], [27], an optimisation approach is adopted for calculating the maximum fuel economy in the early design stage, so that the system provides optimal performance for the worst case scenario.

As the primary goal of this study is to assess the battery impact on fuel consumption at the early design stage using an optimisation process, an offline optimisation method is selected for this study. The optimisation is defined over a typical high-demanding taxiing profile known to be a worst-case taxiing cycle (i.e., input to the optimisation problem), and over a preselected pool of high-power (HP) and high-energy (HE) batteries suitable for more electric aircraft applications. Hence, the fuel minimisation is performed for each battery, which results in a set of optimal solutions whose performance depend on the corresponding battery size (usable energy) and its specifications. This set of solutions is also assessed in terms of added weight (battery weight minus fuel saved) since weight reduction is one of the main drivers in aerospace engineering [28]. Therefore, the presented approach could be applied in the early stage design of a hybrid ETS and proposes a feasibility study on 
how the introduction of battery based ESS could reduce fuel consumption during aircraft taxiing. The results of this study can be used as a battery selector tool given the set of constraints and figures of merit such as a weight allowance. Finally, it is shown how three different EMS reflect three different levels of hybridisation between CET and AET from both the fuel consumption and the power distribution perspectives.

The rest of the paper is organised as follows. In Section II, the model of CET is presented including the power plant model of the APU. Also, the drive cycle and EMSs are introduced in the same section. The optimisation formulation is detailed in Section III, while the results are shown in section IV for each EMS. Limitations and guidelines for future work are discussed in section V. Finally, Section VI concludes the paper.

\section{ELECTRIC TAXIING SYSTEMS MODELLING}

The exploration of a hybrid ETS at the early design stage requires the representation of the system in terms of power and energy flows. The selected ETS architecture for the feasibility study is explained in detail in this section II, and the power and energy requirements for this particular system are presented in II.A. The benefits and drawbacks of this CET power system are assessed, with emphasis on the fuel consumption, which is thoroughly explained in II.B analysing emission rates as well. Finally, three levels of hybridisation are defined in II.C.

\section{A. Power and Energy Requirements}

The main landing gear (MLG) of an ETS for Boeing 737-400 aircraft (narrow-body aircraft) is studied. It utilises traction motors (TMs) specifically designed for the ETS application [29]. The analysed ETS consists of two high torque density gear-less TMs, each mounted directly inside the wheel of the respective MLG (i.e., left ' $L$ ' and right ' $R$ ') [30]. The TM is an outer rotor double star three-phase permanent magnet synchronous motor powered from two separate 2-level voltage source inverters (VSIs) connected to the same DC-link [31], as depicted in Fig. 1. The maximum traction torque that this ETS can produce is $14 \mathrm{kNm}$ with maximum continuous shaft output power at the wheels of $100 \mathrm{~kW}$. 


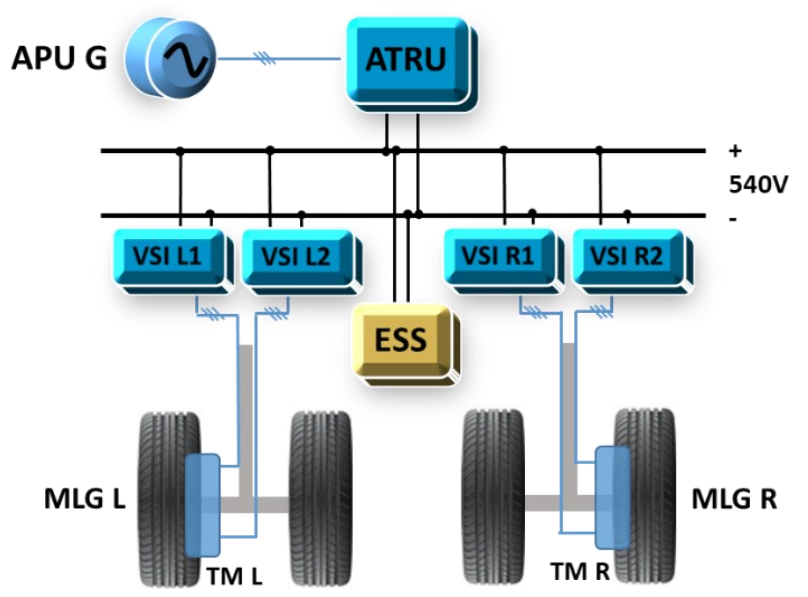

Fig. 1. A schematic of the MLG on-board ET system with one TM per MLG using 2x3-phase windings.

The energy and power requirements of this ET drive have been analysed in [32] for a typical taxi-out speed cycle and Boeing 737-400 aircraft. This analysis consists in modelling the whole ETS powertrain, including aircraft longitudinal dynamics and road conditions. The drive is modelled using the forward approach, allowing for the implementation of the physical limitation of powertrain components and reproducing physical causality of the system [33]. A simplified two-dimension longitudinal dynamics model provides the analytical framework to study the aircraft kinematic performance and the analytical method detailed in [32] is followed. The input to this method is a typical high-demand taxi-out speed cycle with a duration of 30 minutes (1800 s) with kinematic performance in line with those defined by the Electric Green Taxiing System [34]. The maximum achievable speed of the ET is 20 knots, with acceleration from standstill to maximum speed to be achieved in $90 \mathrm{~s}$. The main output of this model is the power required/regenerated at the DC link which is then used for defining the energy and power requirements, as plotted in Fig. 2. It can be seen that the maximum motoring power at the DC link $\mathrm{P}_{\text {taxi }}^{\max }{ }^{\operatorname{mot}}$ is $144 \mathrm{~kW}$, whereas maximum regeneration power $\mathrm{P}_{\text {taxi }}^{\max , \text { reg }}$ is $95 \mathrm{~kW}$. The total energy required for this taxiing cycle is $22.6 \mathrm{kWh}$.
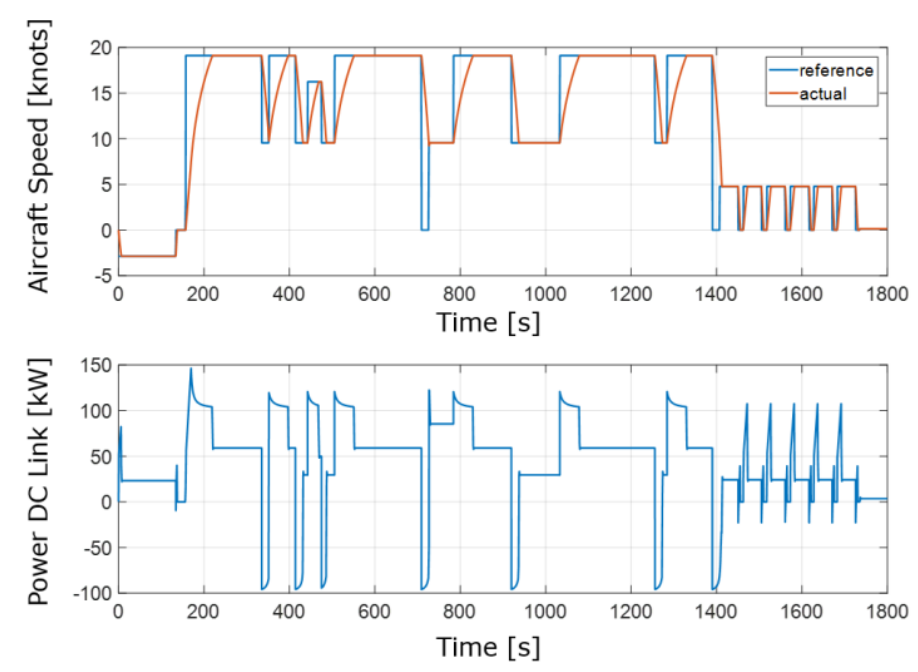

Fig. 2. Speed and power at the DC link for typical taxi-out cycle [32]. 
It is evident that the desired ET kinematic performance cannot be achieved using an APU as the sole power source, as it has a continuous power rating $\mathrm{P}_{\mathrm{e}}^{\text {cont }}$ of $90 \mathrm{kVA}$ and peak rating $\mathrm{P}_{\mathrm{e}}^{\max }$ of $120 \mathrm{kVA}$ [35]. Comparing Fig. 2 and Fig. 3, it can be seen that $\mathrm{P}_{\mathrm{e}}^{\text {cont }}$ is exceeded during acceleration phases 10-20 knots and it is within the peak limit. Additionally, the duration of those peaks is around $30 \mathrm{~s}$, which is an acceptable overload time for an APU generator [35]. On the other hand, during acceleration from standstill to 20 knots, $\mathrm{P}_{\mathrm{e}}^{\max }$ rate is exceeded by $20 \%$. Thus, the introduction of the ESS to the CET busbar (DC link) will not only improve the fuel economy, but also it will keep the APU generator within safety limits, while supporting the needed kinematic performance.

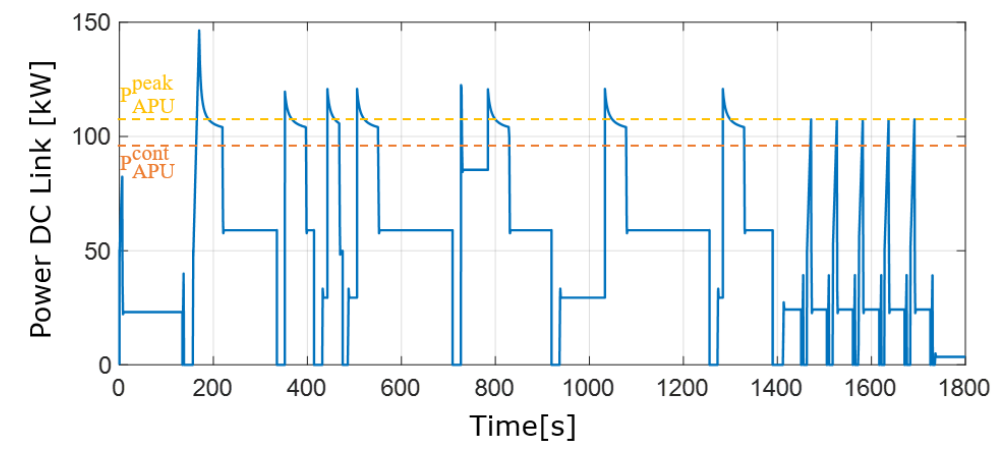

Fig. 3. Traction power profile with the APU generator limits (regeneration is not shown).

\section{B. APU Fuel consumption and emissions in taxiing}

The APU fuel consumption model is difficult to obtain as a large number of thermodynamic properties of the engine are involved in energy production [36]. However, a simplified model in terms of the input/output relationship between fuel consumption and electrical power produced at the electrical generator (APU driven) is required. The intention is to analyse the impact of APU power variations on fuel consumption. This is equivalent to the power plant modelling technique extensively used in the power generation field [37] via successive tests at different loading levels, such that a fitting curve algorithm is used to fit the measured data. In this model, the APU fuel consumption rate can be expressed in terms of power production, and this relationship is appropriate for fuel estimation, having obtained the power requirements at the DC link. This approach has been practised on a APU in [38] and this model has been adopted. Thus, the APU fuel consumption rate curve is shown in Fig. 4 and it can be characterised by (1).

$$
f\left(P_{e}\right)=0.0208+7.366 \times 10^{-5} P_{e}-9.547 \times 10^{-8} P_{e}^{2}
$$




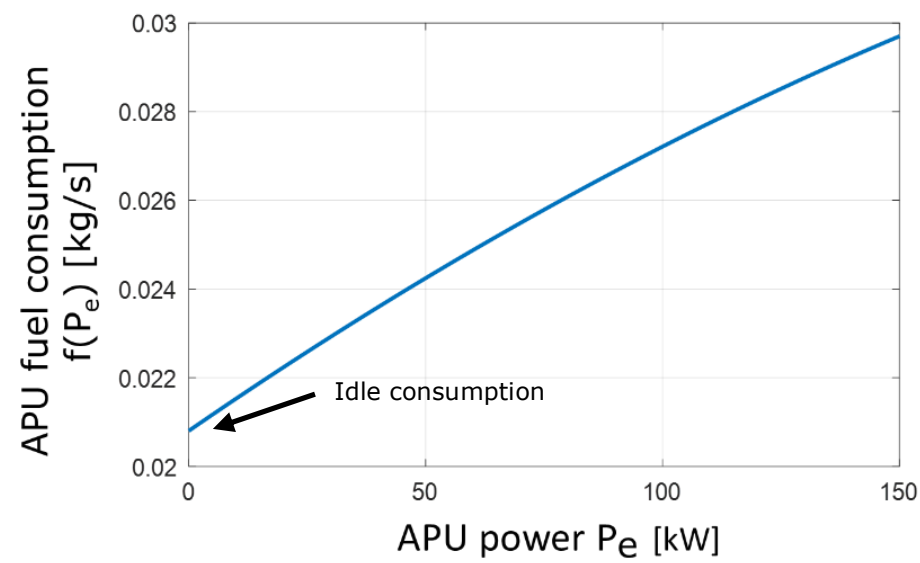

Fig. 4. APU fuel consumption (input) versus the APU power (output) [38].

In (1), $\mathrm{P}_{\mathrm{e}}$ is in $\mathrm{kW}$, and $\mathrm{f}\left(\mathrm{P}_{\mathrm{e}}\right)$ is in $\mathrm{kg} / \mathrm{s}$. Applying (1) to the taxiing power profile of Fig. 3 (excluding regeneration power), it is calculated that $44.3 \mathrm{~kg}$ of fuel is needed for CET. However, it is important to emphasise that when APU is in idle mode (i.e., $\mathrm{P}_{\mathrm{e}}=0$ ), it still burns fuel. If the APU is in idle during the whole taxi-out profile of 30 minutes, it burns $37.44 \mathrm{~kg}$, which means that effectively for ET, only $6.84 \mathrm{~kg}$ of fuel is needed (effective taxiing fuel). Furthermore, as the amount of burnt fuel directly affects the quantity of emitted pollutant gasses, the emission savings are also evaluated in this paper. In TABLE I. , emission indices for narrow-body jet engines and APU are listed whereas the total emissions for a 30 minute taxiing cycle are in TABLE II.

TABLE I. EMISSION RATES (IN $g / k g$ OF FUEL).

\begin{tabular}{|c|c|c|c|c|}
\hline & HC & CO & $\mathbf{N O}_{\mathbf{X}}$ & $\mathbf{C O}_{\mathbf{2}}$ \\
\hline Jet engine & 1.40 & 17.6 & 4.0 & - \\
\hline APU & 0.29 & 4.94 & 7.64 & 3.15 \\
\hline
\end{tabular}

TABLE II. TOTAL FUEL CONSUMPTION AND EMISSIONS FOR 30 MINUTES OF TAXIING.

\begin{tabular}{|c|c|c|c|c|c|}
\hline & $\begin{array}{c}\text { Fuel } \\
{[\mathbf{k g}]}\end{array}$ & HC $[\mathbf{k g}]$ & $\mathbf{C O}[\mathbf{k g}]$ & $\begin{array}{c}\text { NOx } \\
{[\mathbf{k g}]}\end{array}$ & $\begin{array}{c}\mathbf{C O}_{2} \\
{[\mathbf{k g}]}\end{array}$ \\
\hline CT (jet engines) & 364 & 0.5 & 6.4 & 1.5 & - \\
\hline CET (APU) & 44.3 & 0.013 & 0.22 & 0.34 & 0.14 \\
\hline
\end{tabular}

Considering that there is an idle fuel consumption on the APU regardless of the taxiing demand in CET, a larger amount of fuel could be saved if the APU is shut down for some time during taxiing. Besides, it is possible to set a condition where the battery is discharged as much as possible or request it to reach a certain energy value at the end of the taxiing period, so that it is ready for a new taxiing cycle. The former requires charging/swapping batteries during the ground turn-around time, while the latter requires a certain amount of fuel to recharge the battery during taxiing. Therefore, these considerations lead to the formulation of three strategies depending on the level of hybridisation. 


\section{Energy management strategies}

In the first strategy, the ESS and APU run in parallel and the ESS's energy at the end of taxiing is equal to that at the beginning. Next, in the second strategy, the ESS's energy is left unconstrained and fuel savings are expected to increase; yet, both the ESS and APU run in parallel for the entire taxiing period. These two strategies are commonly addressed in series hybrid electric vehicle researches with the exception that in this case the APU could not be subjected to recurring on-off pattern [39], [40]. Instead, the APU is subject to idle mode. Therefore, a third strategy is introduced which allows the APU to be shut down at the start of the taxiing cycle for a certain percentage of time, during which ESS solely provides the taxiing demand. This strategy is the closest to the top-level (AET) of taxiing electrification, whereas the first two strategies are closer to the bottom-level (CET). In the following section, the optimisation formulations for these strategies are detailed.

\section{OPTIMISATION FORMULATION}

For the purpose of the optimisation formulation, the hybrid ET system's architecture is represented as a DC power system whose power flow diagram is illustrated in Fig. 5. In this formulation it is assumed that the components are highly efficient devices (as high as 96\%), meaning that the system's losses are considered negligible. This is a fairly reasonable assumption as nowadays' electrical machines and power electronics actually achieve high efficiency values [41]-[43]. Since the battery based ESS is unable to meet the load requirements, due to the battery's rating limitations, an add-on device is introduced. This device has bi-directional capabilities, and it could be envisioned as an additional battery or supercapacitor (SC) depending on the design criteria, or it could include a bidirectional converter to provide power exchanges with the rest of the aircraft's electrical power system [44].

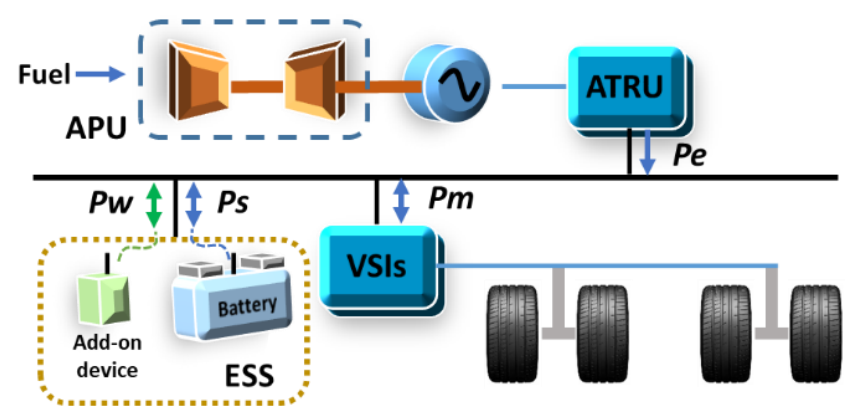

Fig. 5. Hybrid ET system power flow model for optimisation formulation.

The DC link of the ET system is represented as a single bus (ET bus), which receives the unidirectional power $\mathrm{P}_{\mathrm{e}}$ coming from the electrical generator (through an ATRU). All the other components are bi-directional. In this case, $\mathrm{P}_{\mathrm{S}}, \mathrm{P}_{\mathrm{M}}$, and $\mathrm{P}_{\mathrm{W}}$ are the power values of ESS, traction load, and add-on device, respectively. The 
regeneration power from the traction load can be injected to the ET bus to help charge the ESS via $\mathrm{P}_{\mathrm{S}}$, and any remaining power can be directed to the add-on device. Also, the ESS can be discharged to provide traction power either jointly with the APU, or by itself whenever it can drive the taxiing load without APU assistance $\left(P_{e}=0\right)$. Due to the inherent dynamic limitations of the APU's electrical generator and ESS, the add-on device can supply or receive power $\left(\mathrm{P}_{\mathrm{W}}\right)$ when convenient, e.g. improving energy utilisation through another battery, $\mathrm{SC}$, or to the aircraft's power system network.

\section{A. Main Formulation}

The objective of the optimisation formulation is to minimise the taxiing's fuel consumption $F$ for a taxiing profile over a period of time $[1, \mathrm{~T}]$. The outcome of the optimisation is the optimal power distribution between the ESS (battery and add-on device) and the APU's electrical generator. The minimised fuel consumption is associated to the specific battery considered in the optimisation, such that a hybrid ETS comprising this battery would perform the obtained fuel economy. The traction load profile $\mathrm{P}_{\mathrm{M}}$ is known in advance, that is, $\mathrm{P}_{\mathrm{M}}$ is an input. The required traction power $\mathrm{P}_{\mathrm{M}}$ must be supplied by the APU $\left(\mathrm{P}_{\mathrm{e}}\right)$, the ESS's battery $\left(\mathrm{P}_{\mathrm{S}}\right)$, and the ESS's add-on device $\left(\mathrm{P}_{\mathrm{W}}\right)$ as observed in Fig. 5, so that $\mathrm{P}_{\mathrm{e}}, \mathrm{P}_{\mathrm{S}}$, and $\mathrm{P}_{\mathrm{W}}$ are unknown variables to be solved for. The taxiing period is divided into 1800 time steps corresponding to a 30 minutes taxiing $(\mathrm{T}=1800)$, thus, each time step $\mathrm{k}$ has a duration of 1 second, i.e. $\Delta \mathrm{k}=1 \mathrm{~s}$. The APU engine's fuel consumption is assumed to be a function of the APU's power produced at the electrical generator terminals as shown in (1) and Fig. 4. Then, for every time step the fuel consumption is defined as $F(k)=\Delta k \cdot f\left(P_{e}(k)\right)$. The optimisation solution consists of optimal values for fuel consumption $F$, battery power $\mathrm{P}_{\mathrm{S}}(\mathrm{k})$, add-on device power $\mathrm{P}_{\mathrm{W}}(\mathrm{k})$, APU generator power $\mathrm{P}_{\mathrm{e}}(\mathrm{k})$, and ESS's energy $\mathrm{E}(\mathrm{k})$ for each time step $\mathrm{k}$. Therefore, the optimisation objective is as in (2).

$$
\min \sum_{k=1}^{T} \mathrm{~F}(\mathrm{k})=\min _{\mathrm{P}_{\mathrm{e}}, \mathrm{P}_{\mathrm{S}}, \mathrm{P}_{\mathrm{W}}, \mathrm{E}} \sum_{\mathrm{k}=1}^{\mathrm{T}} \Delta \mathrm{k} \cdot \mathrm{f}\left(\mathrm{P}_{\mathrm{e}}(\mathrm{k})\right)
$$

The constraints for this formulation are detailed below. The first constraint is the power balance of the ETS depicted in Fig. 5, i.e., for every time step the demand $\mathrm{P}_{\mathrm{M}}(\mathrm{k})$ is supplied either by $\mathrm{P}_{\mathrm{e}}(\mathrm{k}), \mathrm{P}_{\mathrm{S}}(\mathrm{k}), \mathrm{P}_{\mathrm{W}}(\mathrm{k})$, or a combination of them. For the ET system the power balance constraint can be expressed as in (3), assuming the following sign convention: $\mathrm{P}_{\mathrm{S}}(\mathrm{k})$ is (-) for charging and (+) for discharging conditions; $\mathrm{P}_{\mathrm{M}}(\mathrm{k})$ is $(+)$ when motoring and (-) when regenerating, and $\mathrm{P}_{\mathrm{W}}(\mathrm{k})$ is (-) when absorbing and $(+)$ when injecting.

$$
\mathrm{P}_{\mathrm{M}}(\mathrm{k})=\mathrm{P}_{\mathrm{e}}(\mathrm{k})+\mathrm{P}_{\mathrm{S}}(\mathrm{k})+\mathrm{P}_{\mathrm{W}}(\mathrm{k}) \quad \forall \mathrm{k} \in[1, \mathrm{~T}]
$$


The dynamics of the APU's electrical generator are represented in (4) and (5). Here, $\mathrm{P}_{\mathrm{e}}^{\max r u}$ and $\mathrm{P}_{\mathrm{e}}^{\max r d}$ are the APU's generator maximum ramp-up (positive rate of change) and maximum ramp-down (negative rate of change) powers.

$$
\begin{array}{ll}
P_{e}(k+1)-P_{e}(k) \leq \Delta k \cdot P_{e}^{\max r u} & \forall k \in[1, T-1] \\
P_{e}(k+1)-P_{e}(k) \geq-\Delta k \cdot P_{e}^{\max r d} & \forall k \in[1, T-1]
\end{array}
$$

Assuming that the battery's charging and discharging efficiencies are $\eta_{\mathrm{ch}}$ and $\eta_{\mathrm{dsch}}$ respectively, the ESS's energy $\mathrm{E}$ is calculated as in (6a) and $(6 \mathrm{~b})$, and it is kept within maximum $\left(\mathrm{E}^{\mathrm{max}}\right)$ and minimum limits $\left(\mathrm{E}^{\mathrm{min}}\right)$ as shown in (7),

$$
\begin{array}{cr}
E(k+1)-E(k)=-\Delta k \cdot P_{S}(k) / \eta_{d s c h} & P_{S}(k) \geq 0, \forall k \in[1, T-1] \\
E(k+1)-E(k)=-\Delta k \cdot \eta_{c h} \cdot P_{S}(k) & P_{S}(k)<0, \forall k \in[1, T-1] \\
E^{\min } \leq E(k) \leq E^{\max } & \forall k \in[1, T]
\end{array}
$$

The upper and lower limits are selected to be $90 \%$ and $20 \%$ of total battery energy $\left(\mathrm{E}_{\text {total }}\right)$. Consequently, the depth of discharge is $70 \%$ and the battery's usable energy $\mathrm{E}_{\text {bat }}$ is calculated as $0.7 \mathrm{E}_{\text {total. }}$. Finally, the last constraint regarding ESS's initial energy is reported in (8), where $\mathrm{E}^{0}$ is the initial energy value and it is also constrained by (7).

$$
\mathrm{E}(\mathrm{k}=1)=\mathrm{E}^{0}
$$

The rest of the constraints are related to the upper and lower boundaries for all the power variables. For the APU power, constraint (9) applies, where $\mathrm{P}_{\mathrm{e}}^{\max }$ is the maximum power that can be drawn from the APU's electrical generator. In (10), the battery's power is constrained to $\mathrm{P}_{\mathrm{S}}^{\max , \mathrm{ch}}$ and $\mathrm{P}_{\mathrm{S}}^{\min , \mathrm{dsch}}$, which are the maximum charge and discharge powers respectively, whereas (11) constrains the ESS's add-on power to a maximum value $\mathrm{P}_{\mathrm{W}}^{\max }$.

$$
\begin{array}{cc}
0 \leq \mathrm{P}_{\mathrm{e}}(\mathrm{k}) \leq \mathrm{P}_{\mathrm{e}}^{\max } & \forall \mathrm{k} \in[1, \mathrm{~T}] \\
-\mathrm{P}_{\mathrm{S}}^{\max , \mathrm{ch}} \leq \mathrm{P}_{\mathrm{S}}(\mathrm{k}) \leq \mathrm{P}_{\mathrm{S}}^{\max , \mathrm{dsch}} & \forall \mathrm{k} \in[1, \mathrm{~T}] \\
-\mathrm{P}_{\mathrm{W}}^{\max } \leq \mathrm{P}_{\mathrm{W}}(\mathrm{k}) \leq \mathrm{P}_{\mathrm{W}}^{\max } & \forall \mathrm{k} \in[1, \mathrm{~T}]
\end{array}
$$

Given that the regeneration power can charge the battery, but the battery's charging is limited to $P_{S}^{\max , ~ c h}$, it is possible that some regeneration energy is absorbed by the add-on device. However, the add-on device could also inject power back to the ET system unnecessarily since $\mathrm{P}_{\mathrm{W}}(\mathrm{k})$ participates only in the power balance (3), and it is not accounted for in the optimisation objective (2). In other words, $\mathrm{P}_{\mathrm{W}}(\mathrm{k})$ represents a degree of freedom for which 
there is no penalty in the fuel minimisation objective of (2), leaving open the possibility of finding a suboptimal $\mathrm{P}_{\mathrm{W}}(\mathrm{k})$ and total fuel consumption, or even reaching an inadmissible solution. Therefore, an additional penalty term involving the add-on device power is required in (2), such that the add-on utilisation is minimised. In this case, regeneration power is used as much as possible to charge the ESS (minimum amount of energy directed to add-on device), and unnecessary power from the ESS's add-on device is either avoided entirely, or minimised if essentially required. Then, the problem's objective (2) becomes as in (12).

$$
\min _{\mathrm{P}_{\mathrm{e}}, \mathrm{P}_{\mathrm{S}}, \mathrm{P}_{\mathrm{W}}, \mathrm{E}} \sum_{\mathrm{k}=1}^{\mathrm{T}}\left[\Delta \mathrm{k} \cdot \mathrm{f}\left(\mathrm{P}_{\mathrm{e}}(\mathrm{k})\right)-\Delta \mathrm{k} \cdot \mathrm{P}_{\mathrm{W}}(\mathrm{k})\right]
$$

While the first term in (12) minimises the total taxiing fuel, the second term is equivalent to consider maximization of battery's charging for the time steps where there is regeneration energy available.

\section{B. Energy Management Strategies}

At this point, the three energy management strategies that depend on the level of hybridisation for taxiing electrification can be defined and detailed.

i. Sustained condition- Both the APU's generator and ESS supply taxiing power for the period [1, T]. ESS' battery has a sustained condition, i.e. the battery's energy at the end of the taxiing period is equal to that of the initial value $\mathrm{E}^{0}$, as in (13). Hence, ESS is charged and discharged during $[1, \mathrm{~T}]$.

$$
\mathrm{E}(\mathrm{k}=1)=\mathrm{E}(\mathrm{k}=\mathrm{T})=\mathrm{E}^{0}
$$

ii. Non sustained condition- Both the APU's electrical generator and ESS supply traction power during taxiing period $[1, T]$, but the ESS's battery does not have sustained condition, i.e. the battery's energy at the end of the taxiing period is unconstrained. In this case, the energy at the end of taxiing is not equal to that at the beginning, hence, the battery is predominantly subject to discharging.

iii. APU turned on at $\mathrm{t}_{\mathrm{A}}$ - The taxiing period is divided into two segments. In the first segment, APU is shut down and ESS alone provides traction power until its energy is down to its minimum $\mathrm{E}^{\mathrm{min}}$, which happens at time instant $\mathrm{t}_{\mathrm{A}}$. For the second segment, from $\mathrm{t}_{\mathrm{A}}$ to $\mathrm{T}$, the APU is turned on, and both APU's electrical generator and ESS supply taxiing power for the rest of taxiing period, i.e. $\mathrm{t}_{\mathrm{A}} \leq \mathrm{k} \leq \mathrm{T}$.

For strategies (i) and (ii), $\mathrm{P}_{\mathrm{W}}(\mathrm{k})$ is constrained to be unidirectional, i.e. only absorbing excessive regeneration power, because APU and ESS are capable to supply traction power at every moment. Then, $\mathrm{P}_{\mathrm{W}}(\mathrm{k})$ is constrained to be 0 whenever traction load is not in regeneration mode. Let $r_{t}(k)$ be a Boolean coefficient which is true 
$\left(r_{t}(k)=1\right)$ only on the intervals of time where there is regeneration $\left(P_{M}(k)<0\right)$, and $r_{t}(k)=0$ elsewhere. Thus, $r_{t}$ is a vector of coefficients pre-calculated a priori. Then, (11) is re-written as in (14).

$$
-\mathrm{P}_{\mathrm{W}}^{\max } \mathrm{r}_{\mathrm{t}}(\mathrm{k}) \leq \mathrm{P}_{\mathrm{W}}(\mathrm{k}) \leq 0 \quad \forall \mathrm{k} \in[1, \mathrm{~T}]
$$

Given (14), it is not possible to have regeneration and ESS discharge simultaneously as it is counterintuitive. Therefore, (10) becomes as in (15).

$$
-\mathrm{P}_{\mathrm{S}}^{\max , \mathrm{ch}}\left(1-\mathrm{r}_{\mathrm{t}}(\mathrm{k})\right) \leq \mathrm{P}_{\mathrm{S}}(\mathrm{k}) \leq \mathrm{P}_{\mathrm{S}}^{\max , \mathrm{dsch}} \quad \forall \mathrm{k} \in[1, \mathrm{~T}]
$$

On the other hand, for the third strategy (iii), the APU is shut down during the first segment $1 \leq \mathrm{k} \leq \mathrm{t}_{\mathrm{A}}$ so that there is no fuel consumption at all, and then it is turned on for the rest of the time $t_{A} \leq k \leq T$. It is assumed that the rest of aircraft loads are supplied by a non-APU non-fossil-fuelled secondary generation system during $1 \leq \mathrm{k} \leq \mathrm{t}_{\mathrm{A}}$ (other more electric aircraft systems). Because the ESS has inherent power and energy limitations, the add-on device is the only component that can absorb or supply excessive and deficient energy requirements during the first period $1 \leq \mathrm{k} \leq \mathrm{t}_{\mathrm{A}}$. Therefore, the solution for $\mathrm{P}_{\mathrm{W}}(\mathrm{k})$ provides valuable information to design and size the add-on device during $1 \leq \mathrm{k} \leq \mathrm{t}_{\mathrm{A}}$. Besides, it is also possible that the ESS is sufficient to drive the traction load during all the period $\mathrm{T}\left(\right.$ if $\left.\mathrm{t}_{\mathrm{A}}=\mathrm{T}\right)$.

At this point, it is convenient to summarize the framework of this study as in Fig. 6. Initially, the different levels of hybridisation of ET are introduced according to the fuel economy increase. Then, the three energy management strategies are mapped to the level of hybridisation scale. Afterwards, inputs and constraints of the optimisation formulations are presented. In section IV, the case study and results are presented.

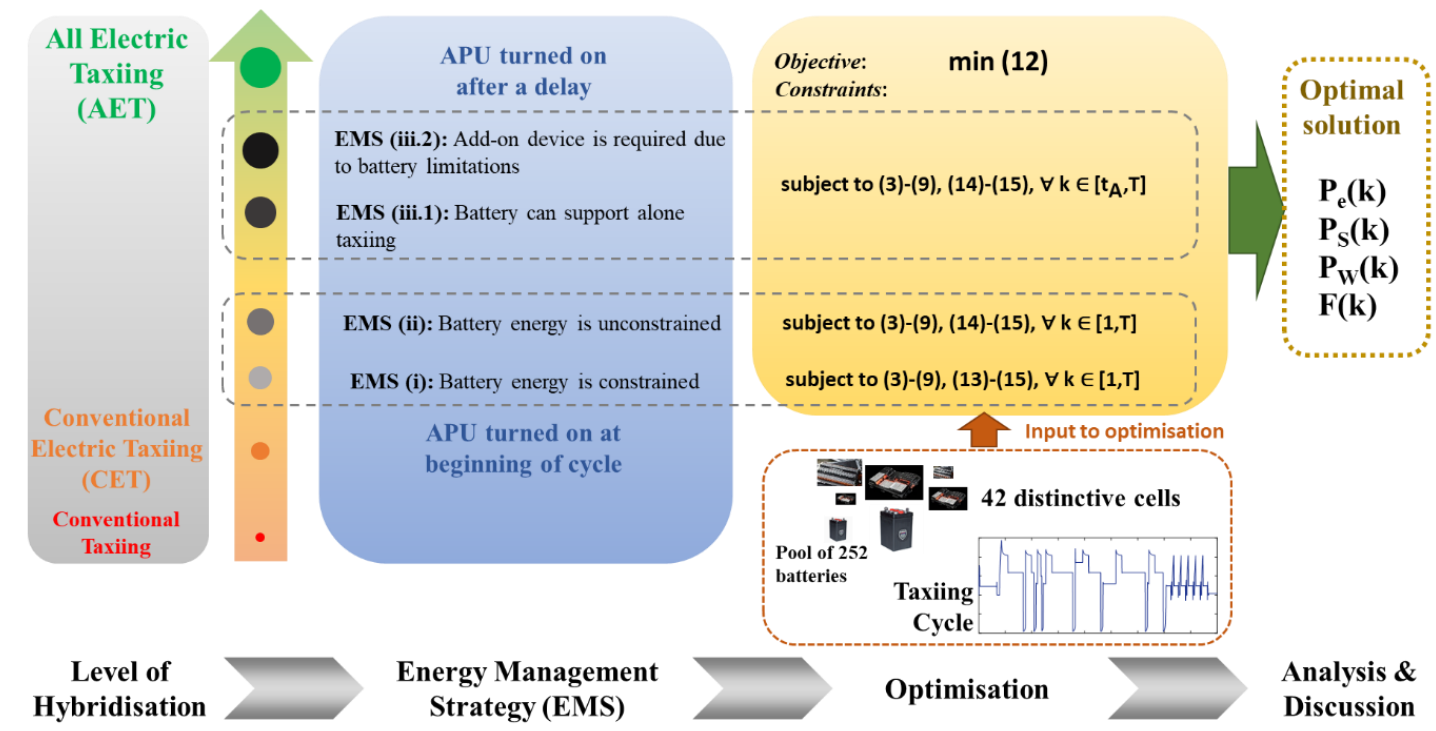

Fig. 6. Framework of the optimisation of the proposed energy management strategies. 


\section{Results}

In this study, the feasibility analysis for the implementation of a hybrid ET for reduced fuel consumption is explored using the three energy management strategies detailed in the previous section. The results for each strategy are presented and discussed in terms of saved fuel. The fuel economy is compared to the CET fuel consumption, i.e. $44.3 \mathrm{~kg}$, due to the reason that CET is the highest level of technology readiness in taxiing electrification currently found and there is no similar hybrid ET benchmark reported in the available literature. The analysis includes the trade-off between the amount of saved fuel and the weight of the ESS, such that some options are recommended. A weight allowance $\mathrm{m}_{\mathrm{A}}=180 \mathrm{~kg}$ is introduced as the suggested weight limit for the implementation of the hybridised ET system. This allowance corresponds to almost half of the fuel required for CT over a 30 minutes taxiing cycle. It is true that the battery's added weight will lead to an increased fuel consumption during flight, however, it has been shown that block-fuel savings could be achieved for an ET system's weight of up to $1000 \mathrm{~kg}$ [16]. Taking into consideration that commercial ET systems weigh approximately $400 \mathrm{~kg}$, the suggested battery weight should not lead to an increase in total block-fuel consumption. Therefore, the analysis excludes the airborne phases, as it is out of the scope of the paper. Additionally, the main target for this study is optimising the ground fuel consumption and emissions. The initial energy of the ESS for the first two strategies is set at $75 \%$ of $\mathrm{E}^{\max }$ to allow some charging from regeneration power and the APU, while the third strategy starts at $95 \%$ of $\mathrm{E}^{\mathrm{max}}$, where the ESS is operating in standalone mode during the first segment of the taxiing cycle. Also, the battery's charging and discharging efficiencies $\eta_{\mathrm{ch}}$ and $\eta_{\mathrm{dsch}}$ are assumed to be 1.0. This assumption allows an unbiased comparison on the fuel reduction potential of different types of batteries, without being compelled to perform further simplifications due to lack of detailed data to build accurate battery models for all brands, types, sizes and power characteristics.

Forty-two cells which are available on the market have been selected from five different brands, specifically: Kokam HE, A123, Saft, Panasonic and Kokam HP. These battery brands have been selected for their technical and economic benefits for traction applications, e.g. electric and hybrid-electric vehicles [45]. The characteristics of each brand are presented in TABLE III. including the number of cells, capacity range, the power to energy ratio $(\mathrm{P} / \mathrm{E})$ range, $\mathrm{C}$ charge rate (the rate at which battery is charged relatively to its capacity), and energy density range. The power to energy ratio $(\mathrm{P} / \mathrm{E})$ has the same value as maximum continuous discharge rate. Furthermore, only continuous discharge operation is considered because there is no consistency in datasheets regarding maximum pulse discharge neither in terms of pulse duration nor relaxation period required after the pulse. By considering this conservative approach, i.e. continuous operation only, the battery's lifetime will be longer which is important for 
taxiing applications. The selection covers both HE and HP cells as well as three different chemistries (lithium nickel manganese cobalt oxide NMC, lithium iron phosphate LFP, and lithium nickel cobalt aluminium oxide NCA).

TABLE III. BATTERY BRANDS FOR ELECTRIC TAXIING SYSTEMS

\begin{tabular}{|c|c|c|c|c|c|c|}
\hline Brand & Capacity [Ah] & P/E ratio & $\begin{array}{c}\mathbf{C} \\
\text { charge } \\
\text { rate }\end{array}$ & $\begin{array}{c}\text { Energy density } \\
{[\mathbf{W h} / \mathbf{k g}]}\end{array}$ & $\begin{array}{c}\text { Type } \\
\text { (chemistry) }\end{array}$ & $\begin{array}{c}\text { Types of cells } \\
\text { investigated }\end{array}$ \\
\hline Kokam HE [46] & $3.3-240$ & $2,3,5$ & 1.5 & $132.14-262.9$ & HE (NMC) & 19 \\
\hline A123 [47], [48] & $2.5-50$ & 20 & 2 & $108.55-139.35$ & HP (LFP) & 3 \\
\hline Saft [49] & $4.0-6.8$ & 2 & 1 & $146-165.46$ & HE (NMC) & 6 \\
\hline Panasonic [50] & 3.4 & 2 & 0.9 & 257.68 & HE (NCA) & 1 \\
\hline Kokam HP [46] & $3.2-200$ & $2,4,5,8,20$ & 1.75 & $127.58-161.57$ & HP (NMC) & 13 \\
\hline
\end{tabular}

Considering that the taxiing energy required is $22.6 \mathrm{kWh}$, and that optimisation is computationally intensive, a set of battery usable energy values ( $\left.\mathrm{E}_{\mathrm{bat}}\right)$ in the range between $5 \mathrm{kWh}$ to $30 \mathrm{kWh}$ (steps of $5 \mathrm{kWh}$ ) are proposed, thus 6 energy sizes per cell type are considered. As a result, a pool of 252 different batteries is generated and the corresponding weight for each battery is reported in Fig. 7. The system's weight increases with the system rating and differs based on the battery brand and type. Using information from TABLE III., each battery's maximum continuous charge $\left(\mathrm{P}_{\mathrm{S}}^{\max , \mathrm{dsch}}\right)$, discharge power $\left(\mathrm{P}_{\mathrm{S}}^{\max , \mathrm{ch}}\right)$, and mass are calculated.

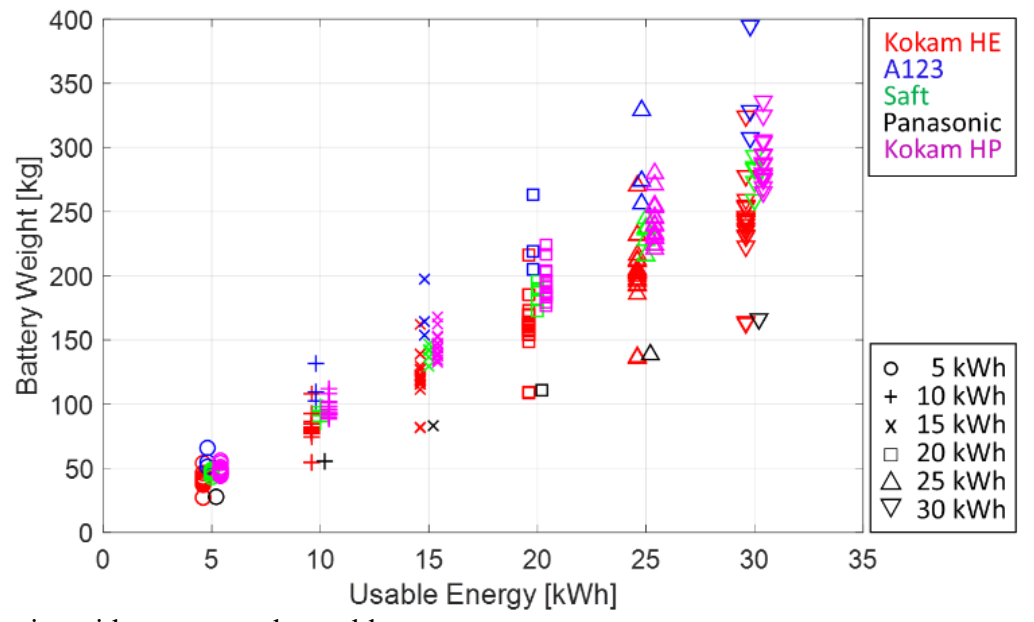

Fig. 7. Weight of batteries with respect to the usable energy.

The optimisation formulations were solved using CPLEX Optimisation Studio 12.9.0 [51] running on a Windows High Spec PC Intel Xeon 64-bit processor at 3.60GHz with 32 GB RAM. Due to the reason that all the constraints are linear, the quadratic objective in (1) was linearized [26], [52] in order to exploit the advantage of solving the optimisation as a Mixed Integer Linear Programming (MILP) problem [53]. In some cases, optimisation is not feasible due to the battery's limitations, and these cases are discarded. The computation time limit to solve an off-line optimisation was set to $3.5 \mathrm{~min}$, the average solving time observed is $97 \mathrm{~s} \mathrm{(1.6} \mathrm{min),} \mathrm{and} 30 \%$ of the optimisations were completed in under $13.5 \mathrm{~s}$ (0.2 $\mathrm{min})$, which is adequate for an early stage design problem. A 
discussion of the applications on real time operational taxiing is presented in section V.D. Although the $\mathrm{m}_{\mathrm{A}}$ is introduced as a suggested weight allowance, the results are presented for a broader range of battery weights depending on their $\mathrm{E}_{\text {bat, }}$, such that the influence of a different $\mathrm{m}_{\mathrm{A}}$ can still be appreciated and further explored if required. The main findings for the rest of the options are discussed below.

\section{A. Strategy (i): sustained condition}

In strategy (i), the APU's electrical generator supplies a certain amount of energy to bring the battery's energy to a specific value at the end of taxiing, i.e. $\mathrm{E}(\mathrm{k}=\mathrm{T})=\mathrm{E}^{0}$, and some regeneration power also charges the battery when possible. The optimisation results are illustrated in Fig. 8; Fig. 8(a) depicts fuel saved with respect to $\mathrm{E}_{\text {bat }}$ while Fig. 8(b) shows fuel saved in terms of battery's weight. In addition to the optimal results, a curve that best fits the optimal points has been included. The expressions for these curves are quadratic and are given in (16)-(17), where $\mathrm{f}^{*}\left(\mathrm{E}_{\text {bat }}\right)$ and $\mathrm{f}^{*}\left(\mathrm{~m}_{\text {bat }}\right)$ represent the optimal fuel saved in $\mathrm{kg}, \mathrm{E}_{\text {bat }}$ is in $\mathrm{kWh}$, and $\mathrm{m}_{\text {bat }}$ is the battery's weight in $\mathrm{kg}$.

$$
\begin{aligned}
& \mathrm{f}^{*}\left(\mathrm{E}_{\text {bat }}\right)=-2.20 \times 10^{-4} \mathrm{E}_{\text {bat }}^{2}+0.0318 \mathrm{E}_{\text {bat }}+0.7904 \\
& \mathrm{f}^{*}\left(\mathrm{~m}_{\text {bat }}\right)=-4.84 \times 10^{-6} \mathrm{~m}_{\text {bat }}^{2}+0.0042 \mathrm{~m}_{\text {bat }}+0.7655
\end{aligned}
$$

Although the battery sizing exercise depends mainly on the fuel economy, usable energy, weight, $\mathrm{P} / \mathrm{E}$ ratio, and brand, (16) and (17) aim to provide a first approximation for battery sizing in terms of a single parameter, where the rest of parameters are implicitly represented. Because the essential sizing parameters are energy, weight, and P/E ratio, the results in Fig. 8 can be fitted in terms of these 3 parameters to obtain a more accurate battery size estimation. This approximation is a 2-variable fuel saved function in terms of $\mathrm{E}_{\mathrm{bat}}$ and $\mathrm{m}_{\text {bat }}$, as in (18), for which its coefficients change depending on the $\mathrm{P} / \mathrm{E}$ ratio, as tabulated in TABLE IV.

$$
\begin{gathered}
\mathrm{g}^{*}\left(\mathrm{E}_{\text {bat }}, \mathrm{m}_{\text {bat }}\right)=\mathrm{a}_{00}+\mathrm{a}_{10} \sqrt{\mathrm{E}_{\text {bat }}}+\mathrm{a}_{01} \sqrt{\mathrm{m}_{\text {bat }}}+\mathrm{a}_{20} \mathrm{E}_{\text {bat }}+\mathrm{a}_{11} \mathrm{~m}_{\text {bat }}+\mathrm{a}_{02} \sqrt{\mathrm{E}_{\text {bat }}^{2}+\mathrm{m}_{\text {bat }}} \\
\text { TABLE IV. COEFFICIENTS FOR FUEL ESTIMATION (18), STRATEGY I }
\end{gathered}
$$

\begin{tabular}{|c|c|c|c|c|c|c|}
\hline $\mathbf{P} / \mathbf{E}$ & $\mathbf{a 0 0}$ & $\mathbf{a 1 0}$ & $\mathbf{a} 01$ & $\mathbf{a 2 0}$ & $\mathbf{a} 11$ & $\mathbf{a 0 2}$ \\
\hline $\mathbf{2}$ & 3.2545 & -2.4010 & 1.1285 & 1.3591 & -0.0205 & -1.2411 \\
\hline $\mathbf{8}$ & 1.6334 & -1.0379 & 0.5538 & 0.5998 & -0.0085 & -0.5596 \\
\hline $\mathbf{2 0}$ & 1.0337 & -0.4355 & 0.2719 & 0.2669 & -0.0034 & -0.2515 \\
\hline
\end{tabular}

Expression (18) and coefficients in TABLE IV. are valid on the vicinity of the batteries selected for each P/E ratio; $E_{b a t}$ is in $\mathrm{kWh}$, and $\mathrm{m}_{\text {bat }}$ is in $\mathrm{kg}$. In other words, (18) is the result of curve fitting exercise with the highest goodness-to-fit ratio (e.g. $\mathrm{SSE}=0.0238, \mathrm{R}^{2}=0.9859$, and $\mathrm{RMSE}=0.0315$ for a $\mathrm{P} / \mathrm{E}$ ratio of 20). For batteries whose useful energy is below $5 \mathrm{kWh}$, the total APU's fuel consumption is reduced by less than $1 \mathrm{~kg}$, as depicted in Fig. 8 (options shown with 'o' marker). However, even with a $30 \mathrm{kWh}$ battery (6 times larger), the saved fuel 
amounts to less than $2 \mathrm{~kg}$, being $1.68 \mathrm{~kg}$ the maximum saving from an A123 $30 \mathrm{kWh}$ battery that has a mass of $307.5 \mathrm{~kg}$, see ' $\nabla$ ' blue markers in Fig. 8. The relative fuel reductions (compared to CET) fall in the range between 2.0 and $4.0 \%$. Below the $\mathrm{m}_{\mathrm{A}}$ (weight allowance), a $30 \mathrm{kWh}$ Kokam HE battery with $\mathrm{P} / \mathrm{E}=2$ and $164.0 \mathrm{~kg}$ provides the maximum fuel saved of $1.54 \mathrm{~kg}$, just $8.3 \%$ less fuel than the A123 $30 \mathrm{kWh}$ batteries at almost half of the weight.

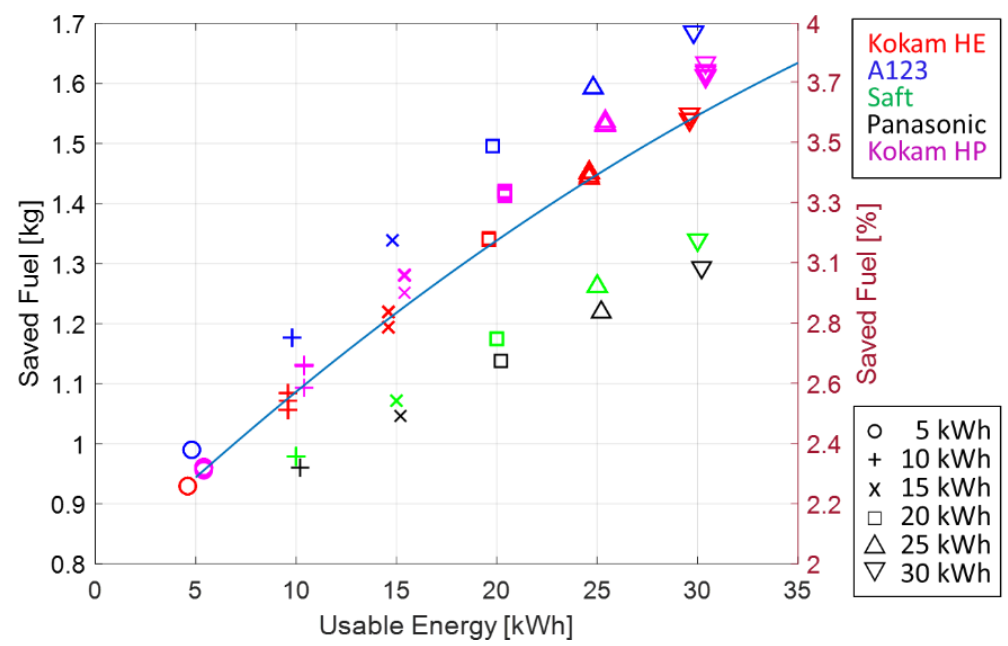

(a)

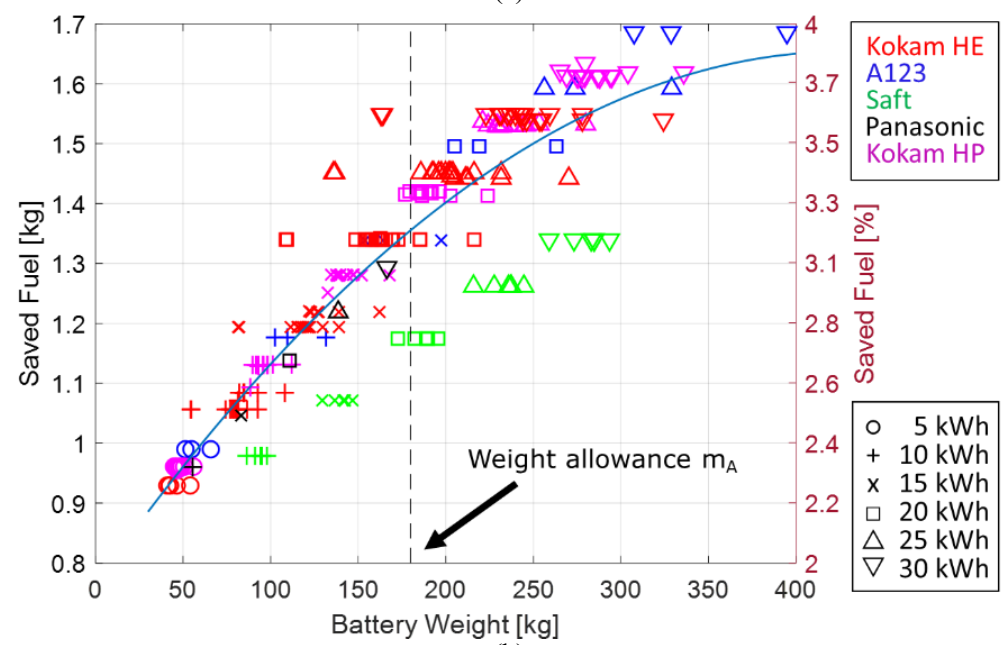

(b)

Fig. 8. Optimal saved fuel for strategy (i), (a) with respect to usable energy, (b) with respect to battery weight.

The minimum saved fuel is $0.93 \mathrm{~kg}$ corresponding to a $5 \mathrm{kWh}$ Kokam HE battery with $\mathrm{P} / \mathrm{E}=5$ and $41.2 \mathrm{~kg}$. In terms of the total added weight, the minimum corresponds to a $5 \mathrm{kWh}$ Kokam HE with $\mathrm{P} / \mathrm{E}=5$ and $41.0 \mathrm{~kg}$. For the rest of the $5 \mathrm{kWh}$ cases, battery mass is between $27 \mathrm{~kg}$ and $65 \mathrm{~kg}$ and it achieves fuel reductions of $1 \mathrm{~kg}$ at most (i.e. 26 to $64 \mathrm{~kg}$ of total added weight). The Kokam HP batteries display an optimal fuel consumption of $1.42 \mathrm{~kg}$ at most for a $20 \mathrm{kWh}$ battery with $\mathrm{P} / \mathrm{E}$ of 8 and a weight of $179.3 \mathrm{~kg}$.

\section{B. Strategy (ii): Non sustained condition}

In strategy (ii), the battery initial energy $\left(\mathrm{E}^{0}\right)$ is the same as in strategy (i), but its final value is unconstrained.

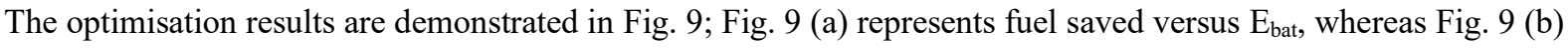


displays fuel saved to $\mathrm{m}_{\text {bat }}$. Similarly to strategy (i), a quadratic equation for fuel economy approximation is used to describe a curve fitting for these results, as listed by (19)-(20),

$$
\begin{gathered}
\mathrm{f}^{*}\left(\mathrm{E}_{\text {bat }}\right)=-4.8 \times 10^{-3} \mathrm{~m}_{\text {bat }}^{2}+0.3608 \mathrm{~m}_{\text {bat }}+0.1768 \\
\mathrm{f}^{*}\left(\mathrm{~m}_{\text {bat }}\right)=-1.0 \times 10^{-4} \mathrm{E}_{\text {bat }}^{2}+0.0400 \mathrm{E}_{\text {bat }}+0.3382
\end{gathered}
$$

In the same manner as in (18), the 2-variable fuel saved function in terms of $E_{b a t}$ and $m_{b a t}$ is used for this strategy, and the values for its coefficients are summarised in TABLE V.

TABLE V. COEFFICIENTS FOR FUEL ESTIMATION (18), STRATEGY II

\begin{tabular}{|c|c|c|c|c|c|c|}
\hline $\mathbf{P} / \mathbf{E}$ & $\mathbf{a}_{\mathbf{0 0}}$ & $\mathbf{a}_{\mathbf{1 0}}$ & $\mathbf{a}_{\mathbf{0 1}}$ & $\mathbf{a}_{\mathbf{2 0}}$ & $\mathbf{a}_{\mathbf{1 1}}$ & $\mathbf{a}_{\mathbf{0 2}}$ \\
\hline $\mathbf{2}$ & -5.538 & 3.123 & 0.382 & 0.2017 & -0.0060 & -0.4657 \\
\hline $\mathbf{8}$ & 20.27 & -22.67 & 11.04 & 11.89 & -0.1688 & -11.15 \\
\hline $\mathbf{2 0}$ & 13.28 & -15.10 & 7.365 & 7.621 & -0.0954 & -7.253 \\
\hline
\end{tabular}

The trend of saved fuel is generally proportional to the battery energy rating, such that the minimum saving is corresponding to the lower $\mathrm{kWh}$ values and vice versa. At $5 \mathrm{kWh}$, the maximum saving is equal to $2.1 \mathrm{~kg}$ of fuel. Conversely, the maximum saving is $16 \%$ of the CET level for batteries rated at $30 \mathrm{kWh}$. Having in mind the weight allowance $\mathrm{m}_{\mathrm{A}}$, two batteries - Kokam HE and Panasonic - rated at $30 \mathrm{kWh}$ emerge, where $6.3 \mathrm{~kg}$ of fuel is saved, weighing 166 and $163 \mathrm{~kg}$ respectively, i.e. a saving 8.7\% less than the maximum possible. For the total added weight criterion, a $5 \mathrm{kWh}$ Kokam $\mathrm{HE}$ with $\mathrm{P} / \mathrm{E}=2$ and $39 \mathrm{~kg}$ of total added weight has a saving of $2 \mathrm{~kg}$ of fuel.

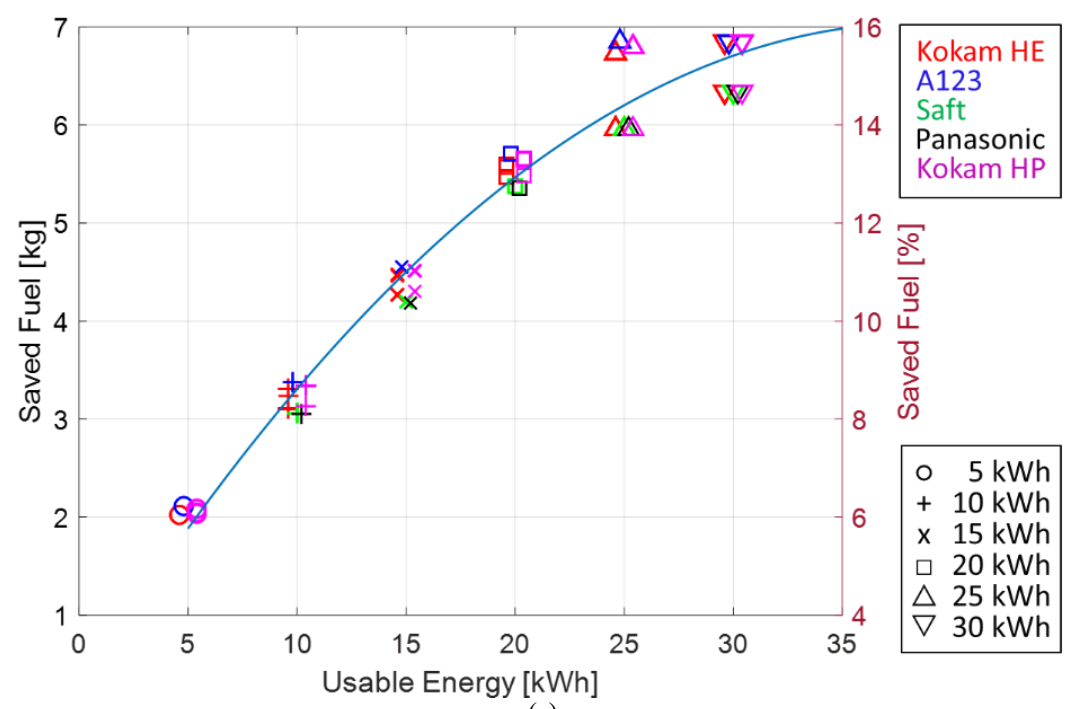

(a) 


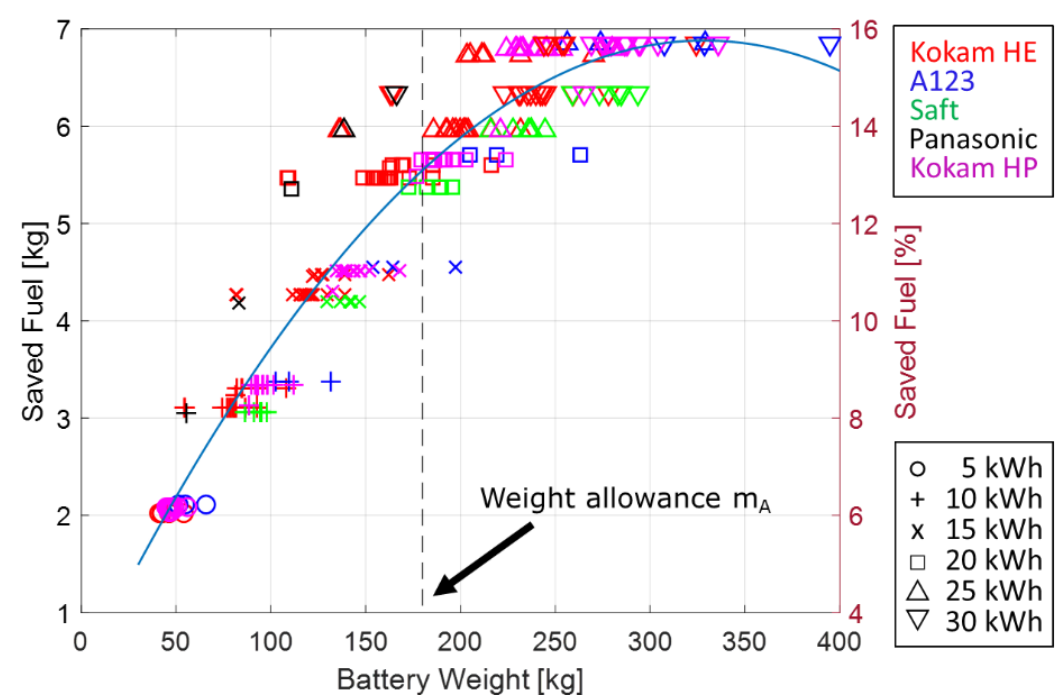

(b)

Fig. 9. Optimal saved fuel for strategy (ii), (a) with respect to usable energy, (b) with respect to battery weight.

C. Strategy (iii): APU turned on at $\mathrm{t}_{\mathrm{A}}$

In this strategy, the APU is completely turned-off during first taxiing period and ETS is fully powered from the ESS. In Fig. 10 the APU activation time is shown for all cases in respect to $\mathrm{E}_{\text {bat }}$ and $\mathrm{m}_{\text {bat }}$. The instant $\mathrm{t}_{\mathrm{A}}$ when the APU turns on depends on the energy content of the battery as well as on its power rating. For example, two Kokam $\mathrm{HE}$ batteries with the same $\mathrm{E}_{\mathrm{bat}}$ of $5 \mathrm{kWh}$ and two different $\mathrm{P} / \mathrm{E}$ ratios, yield different $\mathrm{APU}$ activation times: one with $\mathrm{P} / \mathrm{E}$ equals to 5 it turns on after $\mathrm{t}=605 \mathrm{~s}$, whereas the one with $\mathrm{P} / \mathrm{E}$ of 2 becomes operational after $\mathrm{t}=1374 \mathrm{~s}$. This is because the discharge power of the latter one is lower and consequently the discharge time is higher for the same energy content. Also, it can be concluded that there are cases when the APU never turns on and this occurs for all $30 \mathrm{kWh}$ batteries and the majority of $25 \mathrm{kWh}$ batteries.

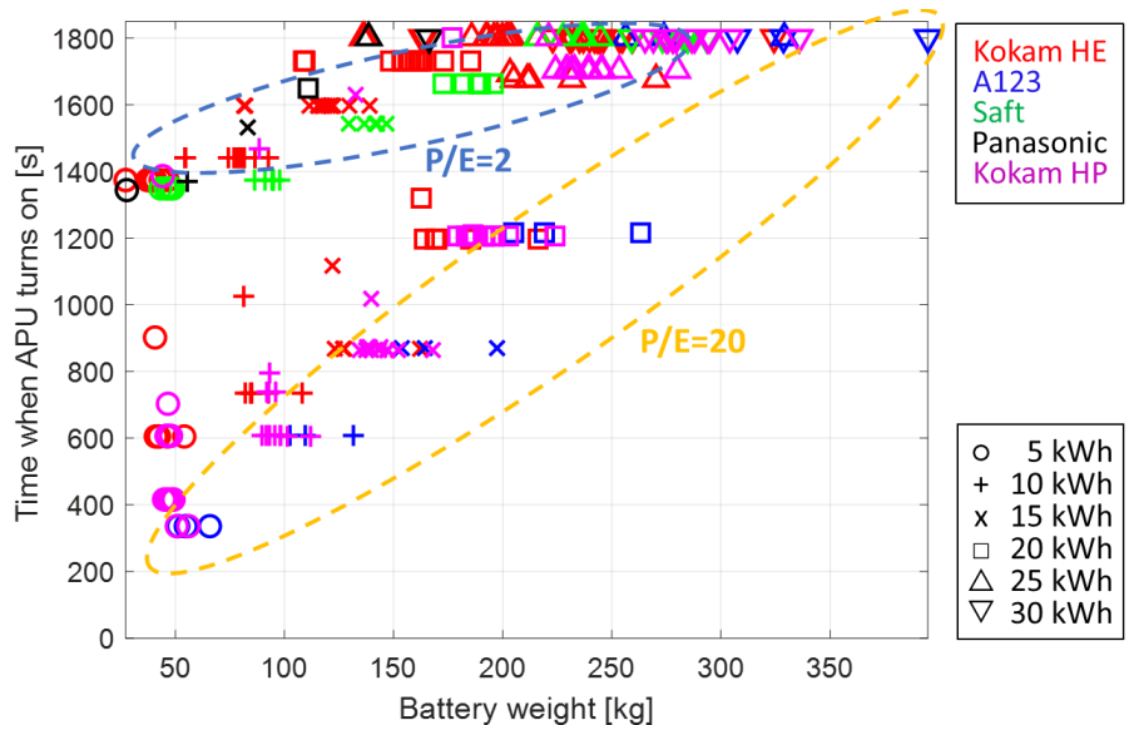

Fig. 10. APU turn on time for different batteries under strategy (iii). 
Even though the APU generator and ESS are managed in optimisation mode after $t_{A}$, most of the fuel savings are obtained before the turn-on time. The more delayed the $t_{A}$ is, the higher the fuel savings are. Thus, the turn-on time $t_{A}$ can be considered as a preliminary estimate of the expected optimal fuel savings, and (21) approximates this time instant as a function of $\mathrm{E}_{\mathrm{bat}}$ and $\mathrm{m}_{\mathrm{bat}}$. In TABLE VI. , the coefficients used in (21) are provided.

$$
\mathrm{t}_{\mathrm{A}}\left(\mathrm{E}_{\text {bat }}, \mathrm{m}_{\text {bat }}\right)=\mathrm{b}_{1}+\mathrm{b}_{2} \mathrm{E}_{\text {bat }}+\mathrm{b}_{3} \mathrm{~m}_{\text {bat }}+\mathrm{b}_{4} \mathrm{E}_{\text {bat }}^{2}+\mathrm{b}_{5} \mathrm{E}_{\text {bat }} \mathrm{m}_{\text {bat }}+\mathrm{b}_{6} \mathrm{~m}_{\text {bat }}^{2}
$$

TABLE VI. COEFFICIENTS FOR APU TURN ON TIME ESTIMATION.

\begin{tabular}{|c|c|c|c|c|c|c|}
\hline $\mathbf{P} / \mathbf{E}$ & $\mathbf{b}_{\mathbf{1}}$ & $\mathbf{b}_{\mathbf{2}}$ & $\mathbf{b}_{\mathbf{3}}$ & $\mathbf{b}_{\mathbf{4}}$ & $\mathbf{b}_{\mathbf{5}}$ & $\mathbf{b}_{\mathbf{6}}$ \\
\hline $\mathbf{2}$ & 1177 & 41.45 & -0.987 & -0.977 & 0.118 & -0.006 \\
\hline $\mathbf{5}$ & 456 & 18.12 & 0.103 & 0.28 & 0.144 & -0.008 \\
\hline $\mathbf{2 0}$ & -16.24 & 61.39 & 0.205 & 0.484 & -0.083 & 0.003 \\
\hline
\end{tabular}

In this strategy, in addition to the optimal saved fuel and battery weight criteria, the battery must be capable of providing the taxiing power requirements alone, i.e. $\mathrm{P}_{\mathrm{S}}^{\max , \mathrm{dsch}}>\mathrm{P}_{\mathrm{taxi}}^{\max }$. Batteries that fulfil this condition are introduced as category I (cat. I). In the other cases when a battery is not sufficient (cat. II), an auxiliary bidirectional source, namely the add-on device, must be added to assist the battery and its weight also should be assessed. Thus, further analysis on the categories cat. I and cat. II is addressed.

\section{1) ESS with battery only (cat. I)}

The simple formula (22) can be used to analytically identify batteries that are within this category.

$$
\mathrm{E}_{\mathrm{bat}}>\frac{0.7 \mathrm{P}_{\text {taxi }}^{\max }}{\mathrm{P} / \mathrm{E} \text { ratio }}
$$

Considering the usable energy range used in this study (i.e. 5-30 kWh), the minimum P/E ratio that fulfils condition (22) is 4, with $\mathrm{E}_{\text {bat }}$ of $30 \mathrm{kWh}$. As the $\mathrm{P} / \mathrm{E}$ increases the set of possible usable energies increases as well. For example, all batteries with $\mathrm{P} / \mathrm{E}$ ratio equal to 20 and with an $\mathrm{E}_{\text {bat }}$ of more than $10 \mathrm{kWh}$ comply with (22). Brands that are in this category are the high-power A123 batteries ( 83\% of selected A123 batteries), most of the Kokam HP batteries ( $\sim 4 \%)$ and few Kokam HE batteries ( $9 \%)$ that exhibit P/E ratio of 5 and have $\mathrm{E}_{\text {bat }}$ of $25 \mathrm{kWh}$ or 30 kWh. All batteries from cat. I and their associated fuel savings are represented in Fig. 11. 


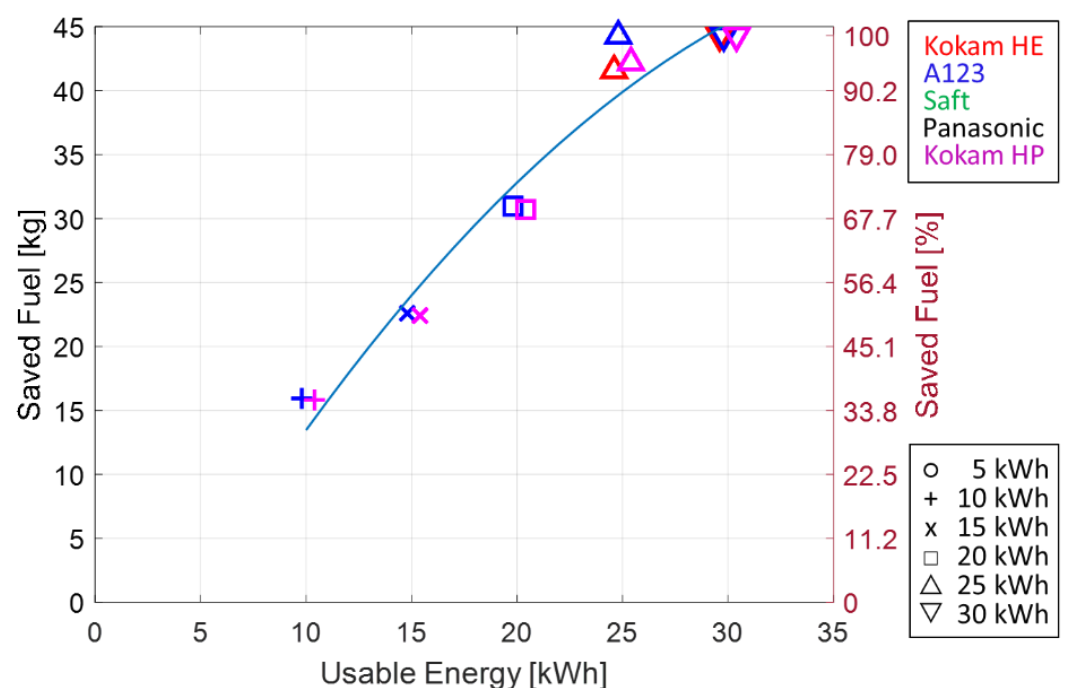

(a)

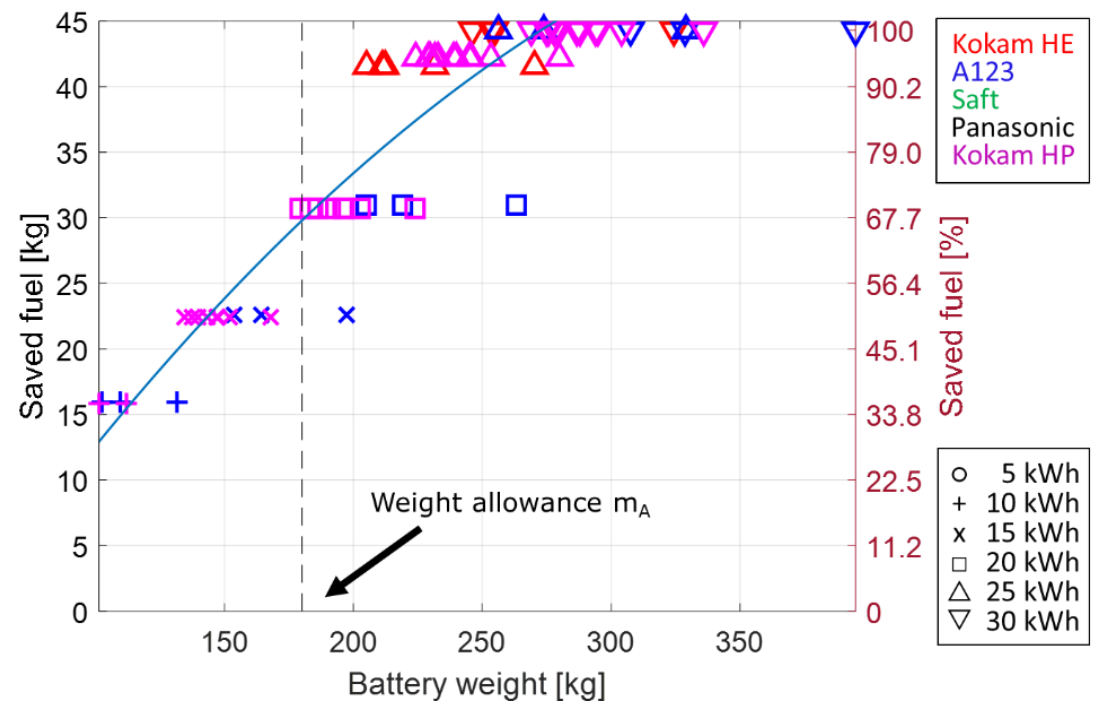

(b)

Fig. 11. Optimal saved fuel for strategy iii, category I with respect to (a) usable energy and (b) battery weight.

Contrarily to the previous two strategies (i) and (iii), a clear saturation trend is noticeable. Practically, all batteries with weights higher than $286.5 \mathrm{~kg}$ result in $100 \%$ fuel savings. In fact, a significant number of options yield savings higher than $95 \%$. The lightest battery that provides $95 \%$ of fuel savings (i.e., $42.08 \mathrm{~kg}$ of fuel) has a mass of $205 \mathrm{~kg}, 14 \%$ higher than the weight limit. This is Kokam HE battery with P/E of 5 and usable energy of $30 \mathrm{kWh}$.

On the other hand, there are only a few batteries that are within the maximum weight limit. Most of them are $10 \mathrm{kWh}$ and $15 \mathrm{kWh}$ A123 batteries and $10 \mathrm{kWh}$ and $15 \mathrm{kWh}$ Kokam HP with P/E ratios of 8 and 20. The battery that saves most fuel $(\sim 70 \%)$ within $\mathrm{m}_{\mathrm{A}}$ limitation is the $180 \mathrm{~kg}$ heavy Kokam HP with P/E of 8 and $20 \mathrm{kWh}$. The fuel savings of cat. I batteries with respect to battery weight and energy rating can be approximated using (18) with coefficients from TABLE VII. 
TABLE VII. COEFFICIENTS FOR FUEL ESTIMATION (18), STRATEGY III FOR BATTERY ONLY.

\begin{tabular}{|c|c|c|c|c|c|c|}
\hline $\mathbf{P} / \mathbf{E}$ & $\mathbf{a}_{\mathbf{0 0}}$ & $\mathbf{a}_{\mathbf{1 0}}$ & $\mathbf{a}_{\mathbf{0 1}}$ & $\mathbf{a}_{\mathbf{2 0}}$ & $\mathbf{a}_{\mathbf{1 1}}$ & $\mathbf{a}_{\mathbf{0 2}}$ \\
\hline $\mathbf{5}$ & -26.07 & 15.04 & 3.427 & 1.429 & -0.0616 & -2.764 \\
\hline $\mathbf{8}$ & $1.23 \mathrm{e} 03$ & $-1.11 \mathrm{e} 03$ & 462.52 & 535.7 & -6.563 & -496.7 \\
\hline $\mathbf{2 0}$ & 121.01 & -123.59 & 53.04 & 58.10 & -0.657 & -53.80 \\
\hline
\end{tabular}

In this category, the minimum total added weight is achieved with Kokam HP, $\mathrm{E}_{\mathrm{bat}}=10 \mathrm{kWh}, \mathrm{P} / \mathrm{E}$ of 20 and $101.5 \mathrm{~kg}$. In this case, the APU turns on at 605 s (i.e. $30 \%$ of the taxiing is performed on ESS itself), thus a significant amount of fuel is burnt $28.4 \mathrm{~kg}$ (15.8 kg savings compared to baseline scenario CET, i.e. $44.3 \mathrm{~kg}$ ). Therefore, the minimum total added weight amounts to $85.7 \mathrm{~kg}$. Similar results are obtained using two Kokam HP batteries with same usable energy and P/E of 20, resulting in $93.6 \mathrm{~kg}$ and $86.5 \mathrm{~kg}$ of total added weight.

\section{2) ESS with both battery and add-on device (cat. II)}

In cat. II there are predominantly batteries created from high energy Saft, Panasonic, and Kokam HE cells. Also, a small number of high-power batteries with low energy content are present, as shown in Fig. 12. Since high energy cells typically exhibit excellent energy densities, these solutions are lighter compared to cat. I batteries. Also, it might appear promising at first glance that almost $100 \%$ of fuel savings can be achieved with lightweight batteries. However, as mentioned earlier, batteries in this category are not powerful enough to sustain electric taxiing alone when the APU is turned off. Therefore, they must be integrated with some other source to bridge this power gap and the weight of that device must be properly assessed and included.

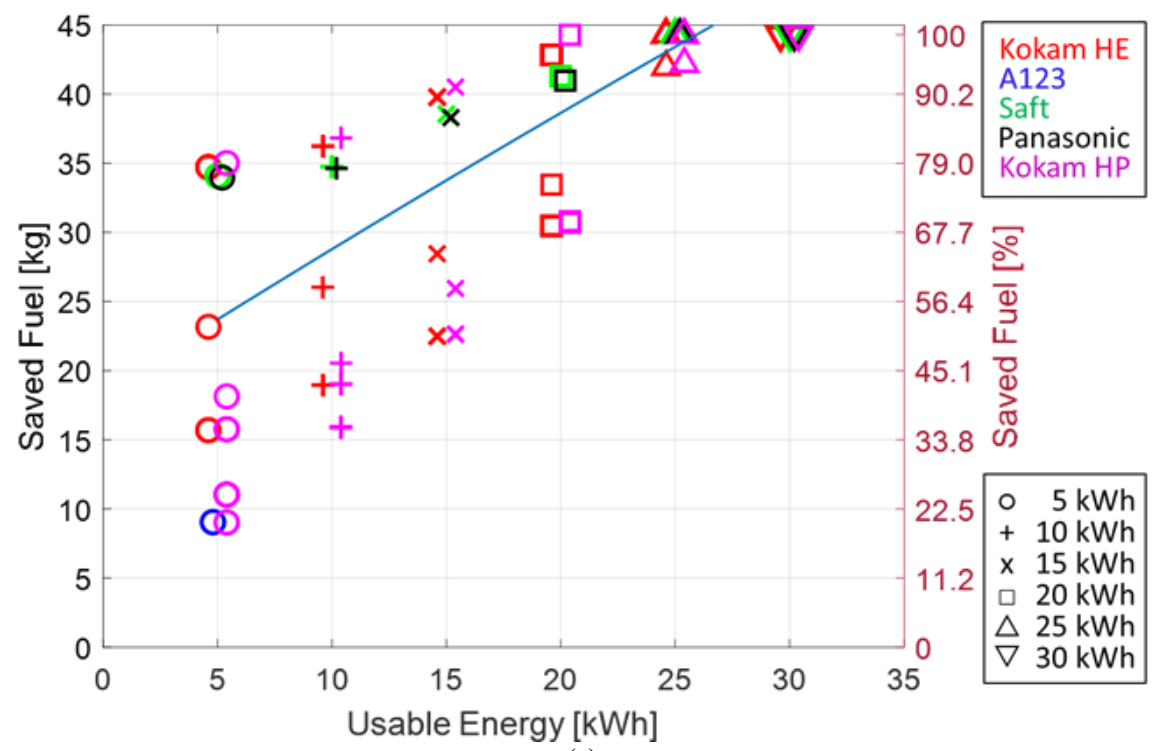

(a) 


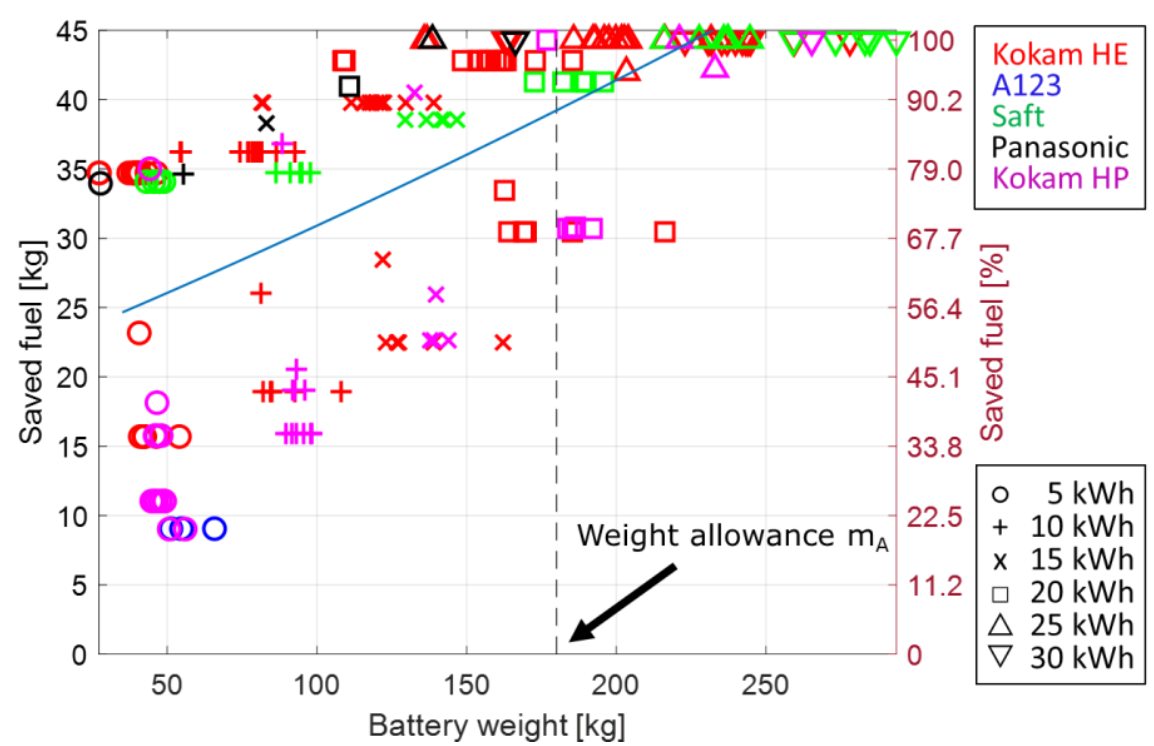

(b)

Fig. 12. Optimal saved fuel for strategy iii, category II with respect to (a) usable energy and (b) battery weight.

To this purpose, $\mathrm{P}_{\mathrm{W}}(\mathrm{t})$ is analysed for each case and, the needed maximum charge and discharge power of the add-on source is obtained as well as the required energy for which the additional device should be sized. The necessary energy is calculated using the maximum swing in energy profile [54], as demonstrated in Fig. 13.
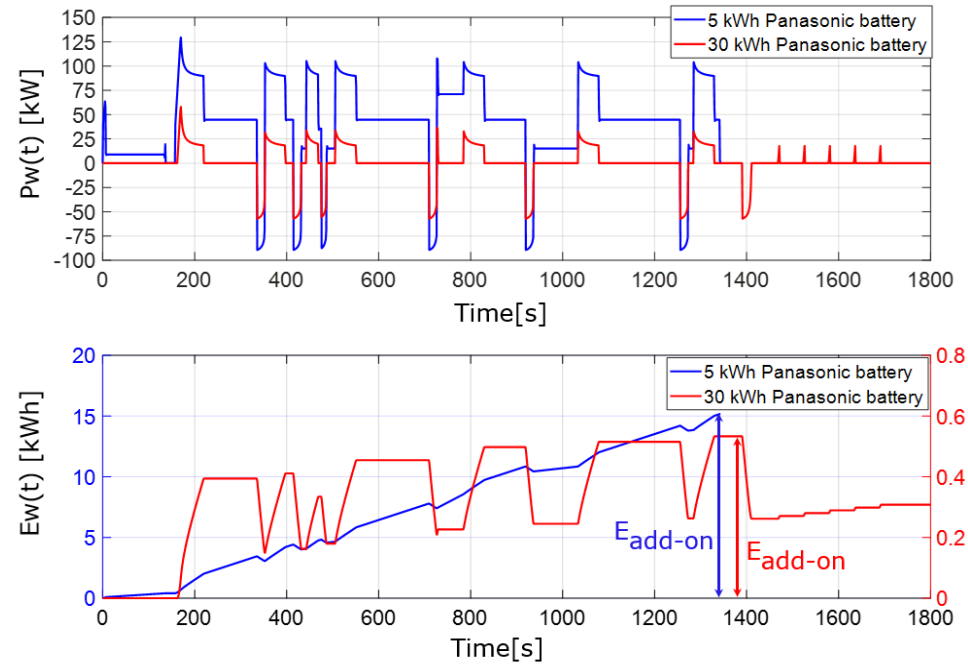

Fig. 13. Power and energy evaluation of the add-on device for Panasonic $5 \mathrm{kWh}$ and $30 \mathrm{kWh}$ batteries, strategy iii, category II.

Obviously, the energy and power requirements of the add-on device are less stringent for the batteries with higher energy content. For example, in TABLE VIII. the requirements of an add-on device are shown for all Panasonic batteries. Furthermore, for high power batteries, the requirements are even more relaxed in terms of energy and power rating, as can be observed in Fig. 14. 
TABLE VIII. The REQUiREMENTS OF ADD-ON SOURCE FOR PANASONIC BATTERIES (P/E RATIO OF 2), STRATEGY III, CAT. II.

\begin{tabular}{|c|c|c|c|c|c|}
\hline $\begin{array}{c}\text { Usable } \\
\text { energy }[\mathrm{kWh}]\end{array}$ & $\begin{array}{c}\mathbf{P}_{\text {bat,dsch }}^{\max } \\
{[\mathbf{k W}]}\end{array}$ & $\begin{array}{c}\text { Mass } \\
\text { battery } \\
{[\mathrm{kg}]}\end{array}$ & $\begin{array}{l}\mathbf{E}_{\text {add-on }} \\
{[\mathbf{k W h}]}\end{array}$ & $\underset{\substack{\text { add-on,dsch } \\
[\mathbf{k W}]}}{\mathbf{m}^{\max }}$ & $\begin{array}{c}\mathbf{P}_{\text {add-on,ch }}^{\max } \\
{[\mathrm{kW}]}\end{array}$ \\
\hline 5 & 14.29 & 27.72 & 15.16 & 129.45 & 89.43 \\
\hline 10 & 28.57 & 55.44 & 10.92 & 115.17 & 83.00 \\
\hline 15 & 42.86 & 83.16 & 7.25 & 100.88 & 76.57 \\
\hline 20 & 57.14 & 110.88 & 3.45 & 86.60 & 70.14 \\
\hline 25 & 71.43 & 138.60 & 1.82 & 72.31 & 63.71 \\
\hline 30 & 85.71 & 166.32 & 0.53 & 58.02 & $\begin{array}{l}57.28 \\
\end{array}$ \\
\hline
\end{tabular}

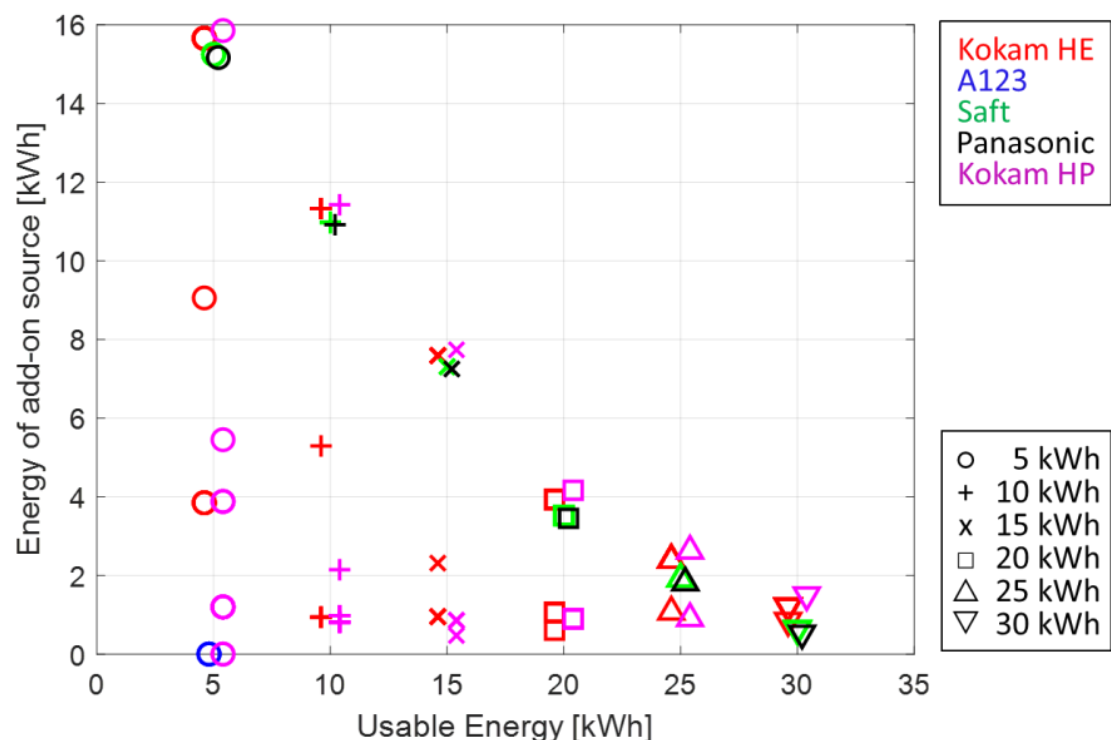

(a)

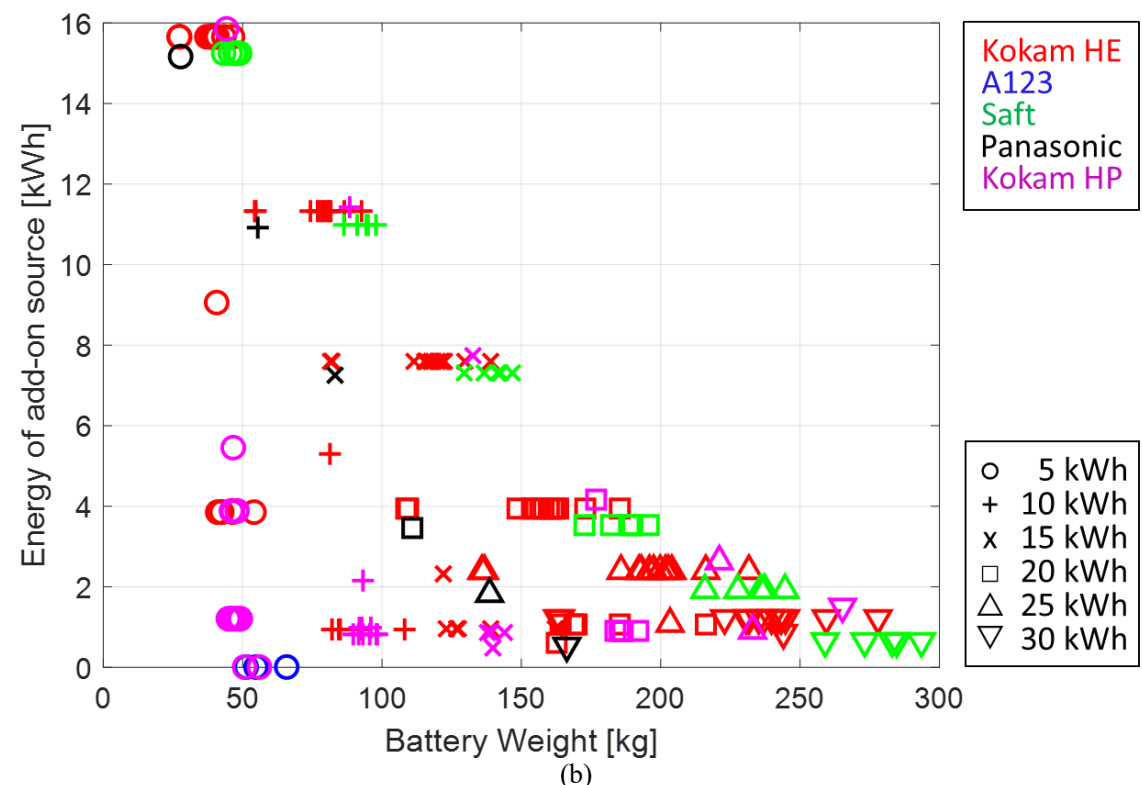

Fig. 14. Energy of the add-on device for strategy iii, category II with respect to (a) usable energy and (b) battery weight.

The add-on device could be any electrochemical device such as SCs, lithium ion capacitors [55] and new battery types such as that proposed in [56], consisting of a hybridisation between HP and HE batteries. It is out of the scope of this paper to analyse all possible options, thus, a SC is going to be considered as it is the most common 
device to be integrated with batteries due to advantages of that configuration [57], [58]. A Maxwell SC [59] cell with a capacitance of $3000 \mathrm{~F}$ and with energy and power density of $6 \mathrm{Wh} / \mathrm{kg}$ and $5.9 \mathrm{~kW} / \mathrm{kg}$ respectively, is selected as the building component of the SC stack. Obviously, due to its inherently low energy density, the SC weight is extremely high when the energy requirement is high as is the case with the Panasonic batteries. In Fig. 15 the fuel savings are presented with respect to the total ESS weight (i.e. battery and add-on device weights), whereas the coefficients of the fuel estimation function (18) are presented in TABLE IX.

TABLE IX. COEFFICIENTS FOR FUEL ESTIMATION (18), STRATEGY III, CAT. II (INTEGRATED BATTERY AND ADD-ON DEVICE).

\begin{tabular}{|c|c|c|c|c|c|c|}
\hline $\mathbf{P} / \mathbf{E}$ & $\mathbf{a}_{\mathbf{0 0}}$ & $\mathbf{a}_{\mathbf{1 0}}$ & $\mathbf{a}_{\mathbf{0 1}}$ & $\mathbf{a}_{\mathbf{2 0}}$ & $\mathbf{a}_{\mathbf{1 1}}$ & $\mathbf{a}_{\mathbf{0 2}}$ \\
\hline $\mathbf{2}$ & 63.30 & -0.3001 & 0.2561 & 2.862 & 0.0483 & -3.546 \\
\hline $\mathbf{5}$ & 86.03 & -47.4 & 2.615 & 8.630 & -0.0364 & -1.908 \\
\hline $\mathbf{8}$ & 4.453 & 1.318 & $5.87 \mathrm{e}-06$ & 0.728 & $-2.55 \mathrm{e}-07$ & $2.24 \mathrm{e}-06$ \\
\hline
\end{tabular}

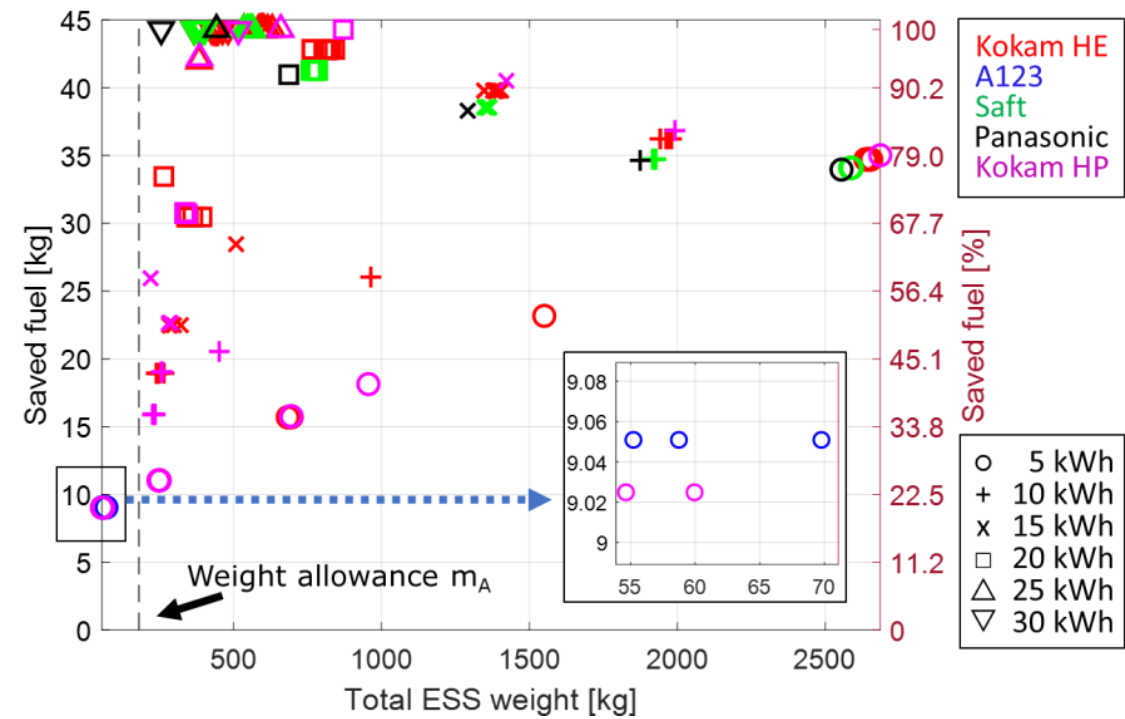

Fig. 15. Optimal saved fuel with respect to total ESS weight, strategy iii, category II.

By inspecting Fig. 15, only 5 batteries and SC combinations fall below $\mathrm{m}_{\mathrm{A}}$ (180 $\mathrm{kg}$ limit). All battery types are high power ones with $\mathrm{P} / \mathrm{E}$ ratio of 20 and $\mathrm{E}_{\mathrm{bat}}$ of $5 \mathrm{kWh}$. Therefore, the best result is achieved when a high-power battery with low energy content is integrated with SC. The data in TABLE X. indicates that the total added weight is between $46.16 \mathrm{~kg}$ and $60.7 \mathrm{~kg}$, which are all lower than the minimum added weight of cat. I of $85.5 \mathrm{~kg}(\sim 50 \%$ less). Thus, in this strategy (iii), it is more beneficial to use high power batteries with low energy content in conjunction with SCs.

TABLE X. TOtAl AdDED Weight FOR BATtERIES OF STRATEGy (III), CAT.II AND SCS THAT ARE BELOW M

\begin{tabular}{|c|c|c|c|c|c|}
\hline Brand & $\begin{array}{c}\text { Mass } \\
\text { battery } \\
{[\mathbf{k g}]}\end{array}$ & $\begin{array}{c}\mathbf{E}_{\text {add-on }} \\
{[\mathbf{k W h}]}\end{array}$ & $\begin{array}{c}\text { Mass } \\
\text { add-on } \\
{[\mathbf{k g}]}\end{array}$ & $\begin{array}{c}\text { Saved } \\
\text { fuel }[\mathbf{k g}]\end{array}$ & $\begin{array}{c}\text { Total added } \\
\text { weight }[\mathbf{k g}]\end{array}$ \\
\hline $\mathbf{A 1 2 3}$ & 65.8 & 6.73 & 3.96 & 9.05 & 60.71 \\
\hline $\mathbf{A 1 2 3}$ & 54.78 & 6.73 & 3.96 & 9.05 & 49.68 \\
\hline $\mathbf{A 1 2 3}$ & 51.26 & 6.73 & 3.96 & 9.05 & 46.16 \\
\hline Kokam HP & 50.68 & 6.75 & 3.96 & 9.02 & 60.71 \\
\hline Kokam HP & 55.98 & 6.73 & 3.96 & 9.02 & 49.68 \\
\hline
\end{tabular}




\section{DISCUSSION AND RECOMMENDATIONS}

Having obtained the results presented in section IV, this section V provides a four-part discussion. The first part considers the implications of selecting one of the three energy management strategies. Then, the influence of different charging/discharging efficiencies in the validation of the results is briefly addressed. Due to the reason that only one high-demanding taxiing cycle has been examined, the impact of other drive cycles is reviewed. Finally, a brief account on the potential for the optimisation formulation presented in this paper, for operational applications in real-time taxiing, is assessed.

\section{A. Energy management strategies analysis}

Strategies (i) and (ii) are conceived as a potential early step in hybridisation towards AET, bringing closer together CET and AET. Besides fuel reduction, ESS also helps to achieve taxiing kinematic requirements without overloading the APU's generator. These strategies can be implemented on current aircraft where the APU is an integral part of the aircraft power generation. Alternatively, strategy (iii) assumes that other aircraft systems are supplied by non-fossil fuel power sources (next generation of aircraft). In fact, it is conceived as the highest level of hybridisation among all strategies (closest to AET) because it allows standalone battery mode until the ESS reaches the lowest permissible energy level, the instant when the APU turns on.

The first two strategies depict the ESS as a single battery whose purpose is to diminish the amount of taxiing fuel supplied by the APU, which is always turned on and also supplies other aircraft systems (different from ETS). Therefore, the theoretical maximum saved fuel in these two strategies is limited by the effective taxiing fuel ( 6.84 $\mathrm{kg}$ ), i.e. $16 \%$ in terms of CET fuel consumption. The fuel reductions in strategy (ii) are larger than in (i), due to the reason that in (i) the APU has to deliver a certain amount of energy to achieve a pre-specified energy content at the end of the taxiing period. Consequently, the fuel reduction in (i) is less than $2 \mathrm{~kg}$ in all of the cases, while it starts at $2 \mathrm{~kg}$ and reaches approximately $6.8 \mathrm{~kg}$ in (ii). In terms of percentage of CET fuel (baseline), strategy (i) saves between $2.0 \%$ and $4.0 \%$ compared to (ii) which saves between $4.0 \%$ and $16 \%$ of taxiing fuel. In both strategies without exception, the minimum total added weight (27.2 kg in (i) and $39 \mathrm{~kg}$ in (ii)) corresponds to the lightest batteries but the least saved fuel. The solutions with the highest fuel reduction unambiguously result in higher total added weight.

More detailed analysis could be performed by obtaining the gradient of the optimal saved fuel function defined in (18). For example in strategy (i), at half of $\mathrm{m}_{\mathrm{A}}$ (battery weight), an increase of $1.8 \times 10^{-3} \mathrm{~kg}$-fuel $/ \mathrm{kg}$-weight is expected for a $10 \mathrm{kWh}$ battery with $\mathrm{P} / \mathrm{E}$ of 20 , which is a sensitivity parameter relating saved fuel and battery weight for a given usable energy. In general, this small number applies to all strategies, which means that the optimal saved 
fuel depends mainly on the $\mathrm{P} / \mathrm{E}$ ratio and $\mathrm{E}_{\text {bat, }}$, rather than on the battery's weight. For instance, at approximately $7.5 \mathrm{kWh}$, the sensitivity is $31.4 \times 10^{-3} \mathrm{~kg}$-fuel $/ \mathrm{kWh}$-energy for a weight of $90 \mathrm{~kg}$ (half of $\mathrm{m}_{\mathrm{A}}$ ) and a P/E of 20 .

In terms of battery size, strategy (i) introduces the least added weight but the least reduction in fuel and consequently emissions. However, the benefit is that the battery requires no time-consuming charging after a taxiing cycle, due to the sustained charge mode, which could save turn-around time and charging electricity cost. Furthermore, with the possibility that the ESS could be switched to a different bus to provide power to other electrical systems during the flight, strategy (i) could be conveniently introduced. In the case of strategies (ii) and (iii), the battery could require a steady charge after taxiing just before switching to other bus. Nevertheless, strategies (i)-(iii) must be carefully justified in terms of regulatory compliance and economic advantages. However, these analyses can be extended in the future. In terms of emission (pollution), the first two strategies provide the figures shown in TABLE XI. for the minimum total added weight scenario. From this table, it can be seen that strategy (ii) has lower emissions compared to (i) $(\approx 1.5 \%$ lower). It also shows that strategy (iii) reduces around $18 \%$ of emissions compared to (i). All of this reflects to cost savings related to noise and pollution penalties that could be avoided.

TABLE XI. FUEL AND EMISSIONS RESULTS FOR MOST PROMISING OPTIONS IN ALL ENERGY MANAGEMENT STRATEGIES.

\begin{tabular}{|c|c|c|c|c|c|c|c|c|c|}
\hline Strategy & $\begin{array}{c}\text { ET Fuel } \\
\text { (kg) }\end{array}$ & $\mathrm{HC}(\mathrm{kg})$ & $\mathrm{CO}(\mathrm{kg})$ & $\mathrm{NO}_{\mathbf{x}}(\mathrm{kg})$ & $\mathrm{CO}_{2}(\mathrm{~kg})$ & $\mathbf{m}_{\text {bat }}(\mathbf{k g})$ & $\begin{array}{c}\begin{array}{c}\text { Ebat } \\
\text { (kWh) }\end{array}\end{array}$ & $\begin{array}{c}\mathbf{P} / \mathbf{E} \\
\text { ratio }\end{array}$ & Brand \\
\hline & \multicolumn{9}{|c|}{ Minimum added weight case } \\
\hline $\mathbf{i}$ & 43.37 & 0.01258 & 0.21425 & 0.33135 & 0.13662 & 41.0 & 5 & 5 & Kokam HE \\
\hline ii & 42.30 & 0.01227 & 0.20896 & 0.32317 & 0.13325 & 41.0 & 5 & 2 & Kokam HE \\
\hline \multirow[t]{2}{*}{ iii } & 35.25 & 0.01022 & 0.17414 & 0.26931 & 0.11104 & $51.2+3.9$ (add-on) & 5 & 20 & A123 \\
\hline & \multicolumn{9}{|c|}{ Maximum fuel saving at weight allowance $m_{A}$} \\
\hline $\mathbf{i}$ & 42.76 & 0.01240 & 0.21123 & 0.32669 & 0.13469 & 164.0 & 30 & 2 & Kokam HE \\
\hline ii & 38.00 & 0.01102 & 0.18772 & 0.29032 & 0.11970 & 163.0 & 30 & 2 & Panasonic \\
\hline iii & 13.60 & 0.00394 & 0.06718 & 0.10390 & 0.04284 & 179.3 & 20 & 8 & Kokam HP \\
\hline
\end{tabular}

In some cases of strategy (iii) an add-on device is required to supply the traction demand completely. This strategy provides savings in the order of $10 \mathrm{~kg}$ to $44.3 \mathrm{~kg}$, which are promising values considering the absence of noise (APU off). However, opposite to (i) and (ii), the total added minimum weight is $85.5 \mathrm{~kg}$ for cat. I and 46.1 $\mathrm{kg}$ for cat. II that are integrated with SC. Even though the total added weight is the highest in this case, from an operational perspective this approach is the best as it saves the highest amount of fuel, it has the highest pollution reduction (TABLE XI. ) and it is practically noise-free at the beginning of the taxiing phase.

\section{B. Different charging/discharging efficiencies}

The battery's efficiency depends on multiple factors, such as the state of charge (SoC), operational temperature, discharge/charge rates. Hence, it is compulsory to have a significant amount of specific information on the batteries' characteristics to develop a comprehensive efficiency model. The assumption of ideal and constant 
charging/discharging efficiencies (i.e. 1.0) allows an unbiased comparison of the potential of several types of batteries under the same conditions for the implementation of a hybrid ETS. In general, the utilisation of a common discharge/charge efficiencies (other than 1) for all batteries would offset all the results towards lower saved fuel regions, or increased fuel consumptions, regardless of the battery type, due to the reason that discharging/charging would account for power losses mainly compensated by the APU's electrical generator. This offset in fuel consumption is roughly constant in magnitude, so that approximations in (16)-(20) are still valid. On the other hand, the optimisation assessment with different efficiencies is possible, however, it requires a set of detailed parameters for each of the 252 batteries considered in this paper, in order to perform the comparison on a more accurate basis. This task could be challenging as several manufacturers do not provide detailed information on their batteries, thus preventing the development of an efficiency model for each separate battery.

\section{Impact of the drive cycles}

It is widely accepted in the automotive sector that drive cycles are useful tools in assessing the performance of vehicles in terms of pollutant emissions and fuel consumption. For example, in the EU, the legislative drive cycle called New European Drive Cycle (NEDC) is in use since 2000, whereas in the US, numerous cycles exist such Urban Dynamometer Driving Schedule (UDDS) and New York City Cycle (NYCC) [60]. All these cycles try to represent common patterns encountered during motorway and urban (city) driving. Unfortunately, such legislative cycles do not exist for ET applications yet. However, most of the ET manufacturers designed their systems to follow Electric Green Taxiing System (EGTS) requirements, namely:

1. Max. speed of 20 knots that should be achieved in $90 \mathrm{~s}$,

2. Speed of 10 knots in $20 \mathrm{~s}$ for active runway crossing,

3. Breakaway torque at $1.5 \%$ grade at MTOW.

The cycle used in this study is constrained by these typical ET taxiing speeds and accelerations. Furthermore, it includes the pushback phase, during which the speed is negative (aircraft is reversing), at the beginning of the cycle, and the queuing phase before take-off at the end of the cycle. The cycle used in [61] follows similar kinematics. In terms of length, the most conservative taxiing time is considered in this paper, i.e., 30 min compared to average taxiing time of $15 \mathrm{~min}$ [62]. This ensures that ESS is assessed for the worst-case scenario, i.e. the longest and highest power demands.

Nonetheless, the driving pattern of ET can affect the EMSs and optimisation itself. As pointed out in [63], there are two types of taxiing cycles, unrestricted and restricted. During the unrestricted one the aircraft taxis to the runway without any stops. On the other hand, during the restricted taxiing cycle multiple stops occur due to 
traffic and active runway crossings. Thus, during one cycle, more than one high-power demanding event can occur, leading to different optimisation outcomes. As it can be seen from Fig. 3 (between $158 \mathrm{~s}$ and $220 \mathrm{~s}$ ), the most power demanding event is the acceleration from 0 to 20 knots (indicated as $a_{0-20}$ ), during which $144 \mathrm{~kW}$ is needed for 30 seconds. During this occurrence, the APU is at its limit of $120 \mathrm{~kW}$ while the ESS provides the rest of $24 \mathrm{~kW}$ for only 10 seconds. Therefore, for instance, if during strategy (iii) $a_{0-20}$ occurs just when the APU turns on, due to optimisation constraints, the power will be provided by the add-on device and APU, as the battery is at its minimum allowed energy when the APU is turned on. However, the battery is still at $20 \%$ of its maximum level, and depending on its size, it can provide either a fraction or all $24 \mathrm{~kW}$ for a time period of 10 seconds. So, in this case additional constraints are required to favour supplementary battery discharge rather than using the add-on device.

\section{Applications on real time operational taxiing}

While the optimisation formulation presented in this paper (see Fig. 6) provides a lower boundary for fuel consumption in the early design of a hybrid electric system, it can be used as a starting point to establish a power management system that optimally distributes the on-line electrical power (real-time taxiing operation). In this case, having deployed the most promising option from the available ones depicted in the results of section IV, the taxiing operation requires a control system that efficiently distributes energy between APU and ESS in order to meet the actual taxiing load demand. Given the extensive use of predictive control methods (e.g. receding horizon control), an operational power management could use a two-stage control methodology consisting of some form of EMS optimisation and a continuously modulated mechanism (e.g. PID, predictive control) in order to exploit pre-driving and on-line power allocation [22], [40], [64]. In the former stage (pre-driving), the system could use a ground movement forecast [4], [65], [66] (e.g. optimal speed profile generation), which is updated periodically based on the changes in airport operation. For example, on a quiet day the initial forecast could even be exempt from further changes as the runway has reduced traffic. In the latter stage (on-line power allocation), control techniques should be rapid and effective to provide fuel economy along sudden traction demand changes.

\section{CONCLUSIONS}

This paper explored the feasibility of hybridising the conventional electric taxiing system supplied by the APU with an additional energy storage system. The analysis is performed on a pool of several types of batteries and, in some cases, it is complemented by a supercapacitor add-on device. Three different energy management strategies, based on the level of hybridisation, were studied for a typical electric taxiing duty cycle of half an hour. The first strategy considers constrained battery's energy at the end of taxiing, while the second strategy relaxes this condition 
and allows battery depletion to a minimum energy level. In the third strategy, APU is turned off in the first period of the taxiing cycle and then a relaxed energy battery condition is ensured for the rest of the cycle; the percentage of time during which the APU is shut down depends on the battery's characteristics. These strategies were formulated as a taxiing fuel minimisation problem constrained by the APU characteristics, battery ratings and power flow balance with the aim of selecting a feasible energy storage for a hybrid electric taxiing system.

The results showed that the highest fuel reductions are achieved for batteries with a high energy rating in the first two strategies. These are the closest to conventional electric taxiing because they are majorly reliant on the APU operation during taxiing. It has been found that up to $14 \%$ of taxiing fuel can be saved, when compared to conventional electric taxiing, by implementing an ESS of $163 \mathrm{~kg}$, which is below the proposed weight allowance of $180 \mathrm{~kg}$. However, considering total added weight, i.e., the difference between battery weight and saved fuel, the best results are achieved for high energy batteries with low usable energy ratings, resulting in a $4.4 \%$ reduction only. In the case of the third strategy, it is possible to achieve a $67 \%$ reduction for a standalone battery option within the weight allowance limit. For a 100\% fuel economy, i.e. the APU is turned off, an ESS of $245 \mathrm{~kg}$ must be implemented, which is $35 \%$ heavier than the suggested weight allowance. The most promising implementation in terms of total added weight in the third strategy, demands an energy storage system consisting of a battery with high power and a low usable energy rating in combination with a supercapacitor.

The results can be further explored in terms of regulatory compliance and economic benefits, airborne fuel consumption implications, different storage types for the complementary add-on device, varying taxiing cycles, and environmental operating conditions.

\section{ACKNOWLEDGMENT}

This work is funded by the INNOVATIVE doctoral programme. The INNOVATIVE programme is partially funded by the Marie Curie Initial Training Networks (ITN) action (project number 665468) and partially by the Institute for Aerospace Technology (IAT) at the University of Nottingham.

\section{REFERENCES}

[1] EASA, "Introduction to the ICAO Engine Emissions Databank Background," 2018. [Online]. Available: https://www.easa.europa.eu/sites/default/files/dfu/171123 Introduction to the ICAO EEDB.pdf.

[2] M. Lukic, P. Giangrande, A. Hebala, S. Nuzzo, and M. Galea, "Review, Challenges, and Future Developments of Electric Taxiing Systems," IEEE Trans. Transp. Electrif., vol. 5, no. 4, pp. 1441-1457, 2019, doi: 10.1109/TTE.2019.2956862.

[3] “Annex 14, Volume I, Aerodrome Design and Operations,ICAO, Montreal, QC, Canada, Jul. 2018, vol. 1.” 
[4] M. Zhang, Q. Huang, S. Liu, and H. Li, “Assessment Method of Fuel Consumption and Emissions of Aircraft during Taxiing on Airport Surface under Given Meteorological Conditions,” Sustainability, vol. 11, no. 21, p. 6110, Nov. 2019, doi: $10.3390 /$ su11216110.

[5] "Honeywell Aerospace. Electric Green Taxiing System. 2013. Available online: https://aerospace.honeywell. com/en/press-release-listing/2013/june/honeywell-and-safran-to-demonstrate-electric-green-taxiing-system-atparis-air-show (accessed on 25 September .”.

[6] "International Air Transport Association. Economic Performance of the Airline Industry: 2015 End-year Report. 2015. Available online: https://www.iata.org/whatwedo/Documents/economics/IATA-Economic- Performance-ofthe-Industry-end-year-2016-report.pdf (acc.”

[7] G. Koudis, "High-resolution evaluation of aircraft emissions at airports," Imperial College London, 2016.

[8] M. Lukic et al., "State of the Art of Electric Taxiing Systems," 2018 IEEE Int. Conf. Electr. Syst. Aircraft, Railw. Sh. Propuls. Road Veh. Int. Transp. Electrif. Conf. ESARS-ITEC 2018, 2019, doi: 10.1109/ESARS-ITEC.2018.8607786.

[9] H. L. Group, “Flightpath 2050: Europe’s Vision for Aviation,” Belgium, 2011. doi: 10.2777/50266.

[10] H. Oyori and N. Morioka, "Power Management System for the Electric Taxiing System Incorporating the More Electric Architecture,” in SAE Technical Papers, Sep. 2013, vol. 7, doi: 10.4271/2013-01-2106.

[11] A. Teo, K. Rajashekara, J. Hill, and B. Simmers, "Examination of Aircraft Electric Wheel Drive Taxiing Concept," in SAE Technical Papers, Nov. 2008, no. 724, doi: 10.4271/2008-01-2860.

[12] "Mototok. Accessed: Jul. 17, 2019. [Online]. Available: https://www. mototok.com/."

[13] L. Khammash, L. Mantecchini, and V. Reis, "Micro-simulation of airport taxiing procedures to improve operation sustainability: Application of semi-robotic towing tractor," 5th IEEE Int. Conf. Model. Technol. Intell. Transp. Syst. MT-ITS 2017 - Proc., pp. 616-621, 2017, doi: 10.1109/MTITS.2017.8005587.

[14] F. Kelch, Y. Yang, B. Bilgin, and A. Emadi, "Investigation and design of an axial flux permanent magnet machine for a commercial midsize aircraft electric taxiing system," IET Electr. Syst. Transp., vol. 8, no. 1, pp. 52-60, Mar. 2018, doi: 10.1049/iet-est.2017.0039.

[15] J. Hospodka, "Cost-benefit analysis of electric taxi systems for aircraft,” J. Air Transp. Manag., vol. 39, pp. 81-88, 2014, doi: 10.1016/j.jairtraman.2014.05.002.

[16] N. Dzikus, J. Fuchte, A. Lau, and V. Gollnick, "Potential for Fuel Reduction through Electric Taxiing," in 11th AIAA Aviation Technology, Integration, and Operations (ATIO) Conference, Sep. 2011, doi: 10.2514/6.2011-6931.

[17] M. T. E. Heinrich, F. Kelch, P. Magne, and A. Emadi, "Regenerative Braking Capability Analysis of an Electric Taxiing System for a Single Aisle Midsize Aircraft," IEEE Trans. Transp. Electrif., vol. 1, no. 3, pp. 298-307, Oct. 2015, doi: 10.1109/TTE.2015.2464871.

[18] J. A. Stockford, C. Lawson, and Z. Liu, "Benefit and performance impact analysis of using hydrogen fuel cell powered e-Taxi system on A320 class airliner," Aeronaut. J., vol. 123, no. 1261, pp. 378-397, 2019, doi: 10.1017/aer.2018.156. 
[19] X. Hu, N. Murgovski, L. M. Johannesson, and B. Egardt, "Comparison of Three Electrochemical Energy Buffers Applied to a Hybrid Bus Powertrain With Simultaneous Optimal Sizing and Energy Management," IEEE Trans. Intell. Transp. Syst., vol. 15, no. 3, pp. 1193-1205, Jun. 2014, doi: 10.1109/TITS.2013.2294675.

[20] F. R. Salmasi, “Control Strategies for Hybrid Electric Vehicles: Evolution, Classification, Comparison, and Future Trends,” IEEE Trans. Veh. Technol., vol. 56, no. 5, pp. 2393-2404, Sep. 2007, doi: 10.1109/TVT.2007.899933.

[21] S. Aoyagi, "Energy efficiency improvement of series hybrid vehicle," JSAE Rev., vol. 22, no. 3, pp. 259-264, Jul. 2001, doi: 10.1016/S0389-4304(01)00100-X.

[22] D. Fares et al., "Optimal power allocation for a FCHV based on linear programming and PID controller," Int. J. Hydrogen Energy, vol. 39, no. 36, pp. 21724-21738, 2014, doi: 10.1016/j.ijhydene.2014.09.020.

[23] J. Peng, H. He, and R. Xiong, "Rule based energy management strategy for a series-parallel plug-in hybrid electric bus optimized by dynamic programming," Appl. Energy, vol. 185, pp. 1633-1643, Jan. 2017, doi: 10.1016/j.apenergy.2015.12.031.

[24] E. D. Tate and S. P. Boyd, "Finding ultimate limits of performance for hybrid electric vehicles," SAE Tech. Pap., 2000, doi: 10.4271/2000-01-3099.

[25] J.-P. Gao, G.-M. G. Zhu, E. G. Strangas, and F.-C. Sun, "Equivalent fuel consumption optimal control of a series hybrid electric vehicle," Proc. Inst. Mech. Eng. Part D J. Automob. Eng., vol. 223, no. 8, pp. 1003-1018, Aug. 2009 , doi: 10.1243/09544070JAUTO1074.

[26] E. Burke et al., Search Methodologies- Introductory Tutorials in Optimization and Decision Support Techniques, 1st ed. UK: Springer Science \& Bussiness Media, 2005.

[27] S. Barsali, C. Miulli, and A. Possenti, “A Control Strategy to Minimize Fuel Consumption of Series Hybrid Electric Vehicles," IEEE Trans. Energy Convers., vol. 19, no. 1, pp. 187-195, Mar. 2004, doi: 10.1109/TEC.2003.821862.

[28] O. H. Morioka Noriko, Takeuchi Michiya, "Moving to an All-Electric Aircraft System," Eng. Rev., vol. 4, no. 1, pp. 33-39, 2014, [Online]. Available: https://www.ihi.co.jp/var/ezwebin_site/storage/original/application/7b9cef85a245dce081106795cab1e65b.pdf.

[29] M. Galea, T. Hamiti, and C. Gerada, “Torque density improvements for high performance machines," Proc. 2013 IEEE Int. Electr. Mach. Drives Conf. IEMDC 2013, pp. 1066-1073, 2013, doi: 10.1109/IEMDC.2013.6556228.

[30] M. Lukic, P. Giangrande, C. Klumpner, and M. Galea, "Modelling and Analysis of an Aircraft On-board Electric Taxiing System,” 2019 22nd Int. Conf. Electr. Mach. Syst. ICEMS 2019, 2019, doi: 10.1109/ICEMS.2019.8921709.

[31] M. Galea, Z. Xu, C. Tighe, T. Hamiti, C. Gerada, and S. Pickering, "Development of an aircraft wheel actuator for green taxiing," Proc. - 2014 Int. Conf. Electr. Mach. ICEM 2014, pp. 2492-2498, 2014, doi: 10.1109/ICELMACH.2014.6960537.

[32] M. Lukic, P. Giangrande, C. Klumpner, and M. Galea, “Analysis of Energy Storage System Requirements for Aircraft Electric Taxiing Operations,” pp. 2616-2621, 2019, doi: 10.1109/iecon.2019.8926797.

[33] L. Guzzella and A. Sciarretta, Vehicle Propulsion Systems. Berlin, Heidelberg: Springer Berlin Heidelberg, 2013. 
[34] T. Johnson, "Electric Green Taxiing System (EGTS) for Aircraft. Available online https://tec.ieee.org/newsletter/march-april-2014/electric-green-taxiing-system-egts-for-aircraft.” .

[35] E. D. Ganev, "Electric Drives for Electric Green Taxiing Systems: Examining and Evaluating the Electric Drive System," IEEE Electrif. Mag., vol. 5, no. 4, pp. 10-24, Dec. 2017, doi: 10.1109/MELE.2017.2757618.

[36] R. Kurz, "Gas turbine performance," in Proceedings of the Thirty-Fourth Turbomachinery Symposium, 2005, pp. 395-406, doi: 10.1016/B978-185617472-5/50033-2.

[37] A. Wood, B. F. Wollenberg, and G. B. Sheble, Power Generation, Operation and Control, 3rd Ed. John Wiley \& Sons, 2013.

[38] F. Re, "Model-based Optimization, Control and Assessment of Electric Aircraft Taxi Systems," 2017, [Online]. Available: http://tuprints.ulb.tu-darmstadt.de/6239/1/Dissertation - Fabrizio Re - Final.pdf.

[39] W. Shabbir, "Control Strategies for Series Hybrid Electric Vehicles,” no. August, 2015.

[40] M. Ceraolo, A. di Donato, and G. Franceschi, “A General Approach to Energy Optimization of Hybrid Electric Vehicles,” IEEE Trans. Veh. Technol., vol. 57, no. 3, pp. 1433-1441, May 2008, doi: 10.1109/TVT.2007.909268.

[41] H. Amano et al., "The 2018 GaN power electronics roadmap,” J. Phys. D. Appl. Phys., vol. 51, no. 16, p. 163001, Apr. 2018, doi: 10.1088/1361-6463/aaaf9d.

[42] M. Henke et al., "Challenges and Opportunities of Very Light High-Performance Electric Drives for Aviation," Energies, vol. 11, no. 344, pp. 1-25, 2018, doi: 10.3390/en11020344.

[43] D. Gerada, A. Mebarki, N. L. Brown, C. Gerada, A. Cavagnino, and A. Boglietti, "High-Speed Electrical Machines: Technologies, Trends, and Developments," IEEE Trans. Ind. Electron., vol. 61, no. 6, pp. 2946-2959, Jun. 2014, doi: 10.1109/TIE.2013.2286777.

[44] L. Tarisciotti, A. Costabeber, C. Linglin, A. Walker, and M. Galea, "Evaluation of isolated DC/DC converter topolog for future HVDC aerospace microgrids," 2017 IEEE Energy Convers. Congr. Expo. ECCE 2017, vol. 2017-Janua, pp. 2238-2245, 2017, doi: 10.1109/ECCE.2017.8096437.

[45] H. C. Bruno Allard, G. Clerc, P. Venet, A. Sari, P. Pommier-Petit, and J. Pallier, "Preliminary Design of Energy Storage System and Bidirectional DC-DC Converter for Aircraft application,” in 2019 IEEE 28th International Symposium on Industrial Electronics (ISIE), Jun. 2019, vol. 2019-June, pp. 2547-2552, doi: 10.1109/ISIE.2019.8781329.

[46] “KOKAM Li-ion/Polymer Cell.” http://kokam.com/data/2019_Kokam_Cell_ver_4.1-compressed.pdf (accessed Jul. 03, 2020).

[47] "Lithium Iron Phosphate (LiFePO4) Battery.” http://www.evlithium.com/A123-Battery/504.html (accessed Jul. 03, 2020).

[48] “A123 Energy Solutions Cells \& Modules.” https://www.buya123products.com/CellsList.php (accessed Jul. 03, 2020).

[49] "Saft lithium batteries." https://directory.ifsecglobal.com/Selector-guide_54083-2-0219-LD-file093890.pdf 
(accessed Jul. 03, 2020).

[50] "Battery Panasonic-Japan.” https:/www.orbtronic.com/batteries-chargers/panasonic-3400mah-18650-li-ion-batterycell-ncr18650b (accessed Jul. 03, 2020).

[51] “IBM ILOG CPLEX Optimization Studio.” https://www.ibm.com/products/ilog-cplex-optimization-studio.

[52] A. A. Recalde, J. A. Atkin, and S. V. Bozhko, "Optimal Design and Synthesis of MEA Power System Architectures considering Reliability Specifications," IEEE Trans. Transp. Electrif., pp. 1-1, 2020, doi: 10.1109/TTE.2020.3002875.

[53] J. P. Vielma, "Mixed Integer Linear Programming Formulation Techniques," SIAM Rev., vol. 57, no. 1, pp. 3-57, Jan. 2015, doi: 10.1137/130915303.

[54] J. Shen, S. Dusmez, and A. Khaligh, "Optimization of Sizing and Battery Cycle Life in Battery/Ultracapacitor Hybrid Energy Storage Systems for Electric Vehicle Applications," IEEE Trans. Ind. Informatics, vol. 10, no. 4, pp. 2112 2121, Nov. 2014, doi: 10.1109/TII.2014.2334233.

[55] J. Ronsmans and B. Lalande, "Combining energy with power: Lithium-Ion Capacitors," in 2016 International Symposium on Power Electronics, Electrical Drives, Automation and Motion, 2016, pp. 261-264.

[56] K. Takeda, C. Takahashi, H. Arita, N. Kusumi, M. Amano, and A. Emori, "Design of hybrid energy storage system using dual batteries for renewable applications," in 2014 IEEE PES General Meeting | Conference \& Exposition, Jul. 2014, pp. 1-5, doi: 10.1109/PESGM.2014.6938860.

[57] S. Pay and Y. Baghzouz, "Effectiveness of battery-supercapacitor combination in electric vehicles," in 2003 IEEE Bologna Power Tech Conference Proceedings, 2003, vol. 3, pp. 728-733, doi: 10.1109/PTC.2003.1304472.

[58] H. Yoo, S.-K. Sul, Y. Park, and J. Jeong, "System Integration and Power Flow Management for a Series Hybrid Electric Vehicle using Super-capacitors and Batteries," in APEC 07 - Twenty-Second Annual IEEE Applied Power Electronics Conference and Exposition, Feb. 2007, vol. 44, no. 1, pp. 1032-1037, doi: 10.1109/APEX.2007.357642.

[59] N. Devillers, S. Jemei, M.-C. Péra, D. Bienaimé, and F. Gustin, "Review of characterization methods for supercapacitor modelling," J. Power Sources, vol. 246, pp. 596-608, Jan. 2014, doi: 10.1016/j.jpowsour.2013.07.116.

[60] E. A. Grunditz, "Design and Assessment of Battery Electric Vehicle Powertrain, with Respect to Performance, Energy Consumption and Electric Motor Thermal Capability," Chalmers University of Technology, 2016.

[61] F. Re, "An Object-oriented Model for Development and Assessment of Green Taxiing Systems," in 3AF Greener Aviation Conference, 2015, no. March 2014, pp. 1-7.

[62] Y. Nicolas, "eTaxi: Taxiing aircraft with engines stopped," Research and Technology Programme Leader Aircraft Control, 2013.

[63] M. T. E. Heinrich, "On the concept of electric taxiing for midsize commercial aircraft: A power system and architecture investigation,” McMaster University, 2015.

[64] A. A. Abdelrauf, W. W. Saad, A. Hebala, and M. Galea, "Model Predictive Control Based PID Controller for PMSM for Propulsion Systems," in 2018 IEEE International Conference on Electrical Systems for Aircraft, Railway, Ship 
Propulsion and Road Vehicles \& International Transportation Electrification Conference (ESARS-ITEC), Nov. 2018, pp. 1-7, doi: 10.1109/ESARS-ITEC.2018.8607585.

[65] J. Chen, M. Weiszer, P. Stewart, and M. Shabani, “Toward a More Realistic, Cost-Effective, and Greener Ground Movement Through Active Routing - Part I: Optimal Speed Profile Generation,” IEEE Trans. Intell. Transp. Syst., vol. 17, no. 5, pp. 1196-1209, 2016, doi: 10.1109/TITS.2015.2477350.

[66] J. Chen et al., "Toward a More Realistic, Cost-Effective, and Greener Ground Movement Through Active Routing: A Multiobjective Shortest Path Approach,” IEEE Trans. Intell. Transp. Syst., vol. 17, no. 12, pp. 3524-3540, Dec. 2016, doi: 10.1109/TITS.2016.2587619. 